(C) 2020 Elsevier. This manuscript version is made available under the CC-BY-NC-ND 4.0 https://doi.org/10.1016/j.bioelechem.2019.107407

\title{
PROMOTING LACCASE SENSING ACTIVITY FOR CATECHOL DETECTION USING LBL ASSEMBLIES OF CHITOSAN/IONIC LIQUID/ PHTHALOCYANINE AS IMMOBILIZATION
} SURFACES

C. Salvo-Comino ${ }^{\mathrm{a}, \mathrm{c}}$, C. Garcia-Hernandez ${ }^{\mathrm{a}, \mathrm{c}}$, C. Garcia-Cabezon ${ }^{\mathrm{b}, \mathrm{c}}$, M.L. Rodriguez-

\author{
Mendez $z^{\mathrm{a}, \mathrm{c}, *}$ \\ ${ }^{a}$ Group UVASens. Engineers School, Universidad de Valladolid, 47011 Valladolid (Spain). \\ ${ }^{b}$ Group UVASens. Materials Science Department, Universidad de Valladolid, 47011 Valladolid \\ (Spain). \\ ${ }^{c}$ BioecoUVA Research Institute, Engineers School, Universidad de Valladolid, 47011 Valladolid \\ (Spain). \\ E-mails: coral.salvo@alumnos.uva.es,celia.garcia.hernandez@uva.es, \\ crigar@eii.uva.es,mluz@eii.uva.es
}

*Corresponding Author: Prof. María Luz Rodríguez-Méndez, Group UVASens, Escuela de Ingenierías Industriales, Paseo del Cauce, 59, 47011 Valladolid. Spain. Phone: +34 983 423540; FAX: +34 983 423310; e-mail: mluz@eii.uva.es

'Declarations of interest: none'. 


\section{ABSTRACT}

The performance of electrochemical laccase-based biosensors can be improved by immobilizing the enzyme on composite Layer-by-Layer (LbL) supports in which materials with complementary functions are combined. LbL films are formed by layers combining an electrocatalytic material which favors electron transfer (sulfonated copper phthalocyanine, $\left.\mathrm{CuPc}^{\mathrm{S}(-)}\right)$, an ionic liquid which enhances the electrical conductivity of the layers (1-butyl-3-methylimidazolium tetrafluoroborate, $\mathrm{IL}^{(+)}$) and a material able to promote enzyme immobilization (chitosan, $\mathrm{CHI}^{(+)}$). Composite films with different structures have been demonstrated to be efficient electrocatalysts, producing an increase in the magnitude of the responses towards catechol. The most intense and reproducible electrocatalytic effect was observed when a layer of the $\mathrm{CuPc}^{\mathrm{S}(-)}$ was placed on top of a layer formed by a mixture of $\mathrm{CHI}^{(+)}+\mathrm{IL}^{(+)}$to obtain $\left[\mathrm{CHI}^{(+)}+\mathrm{IL}^{(+)} \mid \mathrm{CuPc}^{\mathrm{S}(-)}\right]_{2}$ films.

Biosensors with laccase immobilized on the surface of the LbL layers $\left[\mathrm{CHI}^{(+)}+\mathrm{IL}^{(+)} \mid \mathrm{CuPc}^{\mathrm{S}(-)}\right]_{2} \mid$ Lac showed mediated electron transfer between the redox enzyme and the film and a reproducibility of device-to-device performance of $4.1 \%$. The amperometric biosensor showed a sensitivity of $0.237 \mathrm{~A} \cdot \mathrm{M}^{-1}$ and a linear detection range from $2.4 \mu \mathrm{M}$ to $26 \mu \mathrm{M}$ for catechol. The excellent Limit of detection (LOD) of $8.96 \cdot 10^{-10} \mathrm{M}(3 \cdot \sigma / \mathrm{m})$ is one order of magnitude lower than that obtained in similar studies. A Michaelis-Menten constant of $3.16 \mu \mathrm{M}$ confirms excellent enzyme-substrate affinity.

Keywords: Layer-by-Layer; Laccase; biosensor; catechol; phthalocyanine 


\section{INTRODUCTION}

Catechol is a widely studied phenol that occurs naturally in foods and vegetables and is also a common industrial byproduct [1]. A wide range of electrochemical sensors and biosensors dedicated to the detection of phenols have been developed $[2,3]$. This assortment is due to the number of immobilization procedures aimed at improving enzyme functionality. These include: entrapment in sol-gel or hydrogel matrices; incorporation into polymer films; covalent linking to the electrode surface; or immobilization on self-assembled monolayers, LangmuirBlodgett films or the surface of carbon nanotubes; among many others [4-6]. In addition, different electron mediators have been used to facilitate electron transfer between the enzyme and the electrode. These include Prussian blue [7], conducting polymers [4,8,9], nanoparticles [10] or graphene [11,12], among others. The Layer by layer (LbL) technique is an interesting approach for the preparation of enzymatic biosensors, as it provides structures which can be a suitable support for enzyme immobilization [13-15]. In previous studies, LbL films combining polyethyleneimine (PEI) [13,16], polyallylamine hydrochlorate (PAH) [14,17], or chitosan (CHI) -as positively charged species- with poly(styrene sulfonate) (PSS) or polyvinyl sulfonate (PVS) -as polyanions- have been used as substrates for biosensors

The objective of the present study was to explore a new strategy to improve the performance of biosensors using LbL assemblies with a dual functionality. In this approach, LbL films act simultaneously as suitable supports for enzyme immobilization and as efficient electron mediator layers.

An enzymatic electrochemical biosensor for catechol detection was developed for this purpose, in which a phenol oxidase (laccase) was immobilized on LbL films prepared 
with materials selected to preserve and promote enzyme activity and to facilitate electron transfer. The materials chosen included $\mathrm{CHI}^{(+)}$, a natural cationic polyaminosaccharide, which was selected as a cationic polymer since it is a standard support for enzyme immobilization [20-25]. The selection of $\mathrm{CuPc}^{\mathrm{S}(-)}$ was due to its electrocatalytic and film forming properties [4,14,26,27]. A variety of metallophthalocyanines have been used as redox mediators for enzyme based sensor phthalocyanines [28-31]. However, phthalocyanines have the inconvenience of their low conductivity [32]. To improve the conductivity of the sensing layer, an $\mathrm{IL}^{(+)}$was included in the LbL assembly, owing to its high ionic conductivity and electrochemical stability [33-36].

In short, in this work, LbL films combining positively chargadlecules including $\mathrm{CHI}^{(+)}$and $\mathrm{IL}^{(+)}$and a polyanion, $\mathrm{CuPc}^{\mathrm{S}(-)}$ weredesigned. The benefits obtained by the immobilization properties provided by $\mathrm{CHI}^{(+)}$, the electrocatalytic activity of $\mathrm{CuPc}^{\mathrm{S}(-)}$, the high ionic conductivity of the $\mathrm{IL}^{(+)}$and the occurrence of synergetic effects due to interaction between the components were explored. The influence of the architecture of the LbL films in the immobilization of Laccase and on the electron transfer from the enzyme to the electrode were analyzed. Performance of the biosensor was investigated in terms of sensitivity, linearity range, limits of detection and reproducibility.

\section{MATERIALS AND METHODS}

\subsection{Materials and Instruments}

Chitosan $\left(\mathrm{CHI}^{(+)}\right)$(medium molecular weight, $75-85 \%$ deacetylated chitin) (CAS Number: 9012-76-4), copper (II) phthalocyanine-3,4',4"',4"'-tetrasulfonic acid tetrasodium salt $\left(\mathrm{CuPc}^{\mathrm{S}(-)}\right)$, and 1-butyl-3-methyliimidazolium tetrafluoroborate $\left(\mathrm{IL}^{(+)}\right)$ were purchased from Sigma-Aldrich (St. Louis, MO, USA). Laccase enzyme (Lac, from Trametes versicolor, activity of $10 \mathrm{U} \mathrm{mg}^{-1}$, CAS 80498-15-3) and catechol were also 
purchased from Sigma-Aldrich. Glutaraldehyde (50\% aqueous solution) was purchased from Alfa Aesar (Haverhill, MA, USA). Deionized water from MilliQ (resistivity 18.2 $\mathrm{M} \Omega \cdot \mathrm{cm}$ ) was used in all solutions and experiments.

Layer by layer films were prepared using a rotary dip-coater device ND-R from Nadetech (Spain). LbL films were deposited onto different substrates including glass, $\mathrm{ZnS}$, quartz, mica and ITO glass. ITO glass slides were purchased from SIGMA (surface resistivity 15-25 $\Omega / \mathrm{sq}$ ). Mica slides were muscovite Mica V2 quality (Electron Microscopy Science. USA.Cat . 71857-01-10).

UV-Vis characterization was performed using films deposited on quartz substrates in a Shimadzu UV-2600. Fourier Transform Infrared (FTIR) spectra of films deposited on ZnS were obtained using a FTIR 6600 Jasco spectrophotometer from 700 to $2000 \mathrm{~cm}^{-1}$, at a resolution of $4 \mathrm{~cm}^{-1}$ and 1000 scans. Atomic force microscope (AFM) images were recorded in films deposited on mica at room temperature in a NanoScope IIIa operated in tapping mode. Electrochemical measurements were carried out using a potentiostat/galvanostat PGSTAT128 (Autolab Metrohm, Utrecht, Netherlands).

\subsection{Sensor preparation}

Substrates were modified with $\mathrm{LbL}$ films containing $\mathrm{CHI}^{(+)}, \mathrm{CuPc}^{\mathrm{S}(-)}$ and $\mathrm{IL}^{(+)}$. Films with two different preparation sequences were developed.

The first sequence was denoted as $\left[\mathrm{CHI}^{(+)}\left|\mathrm{CuPc}^{\mathrm{S}(-)}\right| \mathrm{IL}^{(+)} \mid \mathrm{CuPc}^{\mathrm{S}(-)}\right]_{\mathrm{n}}$, where $\mathrm{n}$ means the number of repetitions. These films were prepared by incubating an ITO substrate in different solutions (at $21^{\circ} \mathrm{C}$ and $30 \%$ relative humidity) using the following sequence: 1 ) Immersion in a $\mathrm{CHI}^{(+)}$solution $\left(10^{-3} \mathrm{M}\right.$, prepared in acetic acid $\left.0.3 \% \mathrm{v} / \mathrm{v}\right)$ for $5 \mathrm{~min} .2$ ) Washing step by immersion in deionized water for 5 s. 3) Immersion in an aqueous solution of $\mathrm{CuPc}^{\mathrm{S}(-)}\left(5 \cdot 10^{-5} \mathrm{M}\right)$ for $5 \mathrm{~min}$. 4) Washing step in deionized water for $5 \mathrm{~s}$. 5) Immersion in a $10^{-3} \mathrm{M}$ solution of $\mathrm{IL}^{(+)}$during 5 min. 6) Washing in deionized water for 
5 s. 7) Immersion in an aqueous solution of $\mathrm{CuPc}^{\mathrm{S}(-)}\left(5 \cdot 10^{-5} \mathrm{M}\right)$ for $\left.5 \mathrm{~min} .8\right)$ Washing in deionized water for $5 \mathrm{~s}$. This procedure was repeated to increase the thickness

of

the

structures.

The second architecture was obtained by alternating immersions in a solution containing a mixture of positively charged materials $\left(\mathrm{CHI}^{(+)}+\mathrm{IL}^{(+)}\right)(1: 1 \mathrm{v} / \mathrm{v})$ and a solution of the negative $\mathrm{CuPc}^{\mathrm{S}(-)}$ to form $\left[\mathrm{CHI}^{(+)}+\mathrm{IL}^{(+)} \mid \mathrm{CuPc}^{\mathrm{S}(-)}\right]_{\mathrm{n}}$. The procedure was as follows: 1) Immersion in a mixture $\left(\mathrm{CHI}^{(+)}+\mathrm{IL}^{(+)}\right)(1: 1 \mathrm{v} / \mathrm{v})$ for $5 \mathrm{~min}$. 2) Washing with deionized water for 5 s. 3) Immersion in $\mathrm{CuPc}^{\mathrm{S}(-)}\left(5 \cdot 10^{-5} \mathrm{M}\right)$ for 5 min. 4) Washing with deionized water for $\quad 5 \quad$ s. Biosensors were prepared by depositing the enzyme laccase (Lac) on the surface of the LbL films using the following method. After washing the LbL films in $0.01 \mathrm{M}$ phosphate buffer ( $\mathrm{pH}$ 7.00) for $2 \mathrm{~min}$ and subsequent drying, $50 \mu \mathrm{L}$ of a solution containing $5 \mathrm{mg} \cdot \mathrm{mL}^{-1}$ of the enzyme (in a $0.01 \mathrm{M}$ phosphate buffer; $\mathrm{pH} 7.00$ ) were deposited onto the surface. Once dried at room temperature, the enzyme was cross-linked by introducing the device into a desiccator $(20 \mathrm{~cm}$ diameter) containing 20 $\mathrm{ml}$ of a $2.5 \%(\mathrm{v} / \mathrm{v})$ glutaraldehyde solution prepared in $0.01 \mathrm{M}$ phosphate buffer during $20 \mathrm{~min}$ at room temperature. Sensors were washed in order to remove any unbound enzyme from the electrode surface.

\subsection{Electrochemical measurements}

Electrochemical experiments were carried out in a three-electrode electrochemical cell $(50 \mathrm{~mL})$ using the LbL films deposited on ITO glass as the working electrode. Ag| $\mathrm{AgCl}(3 \mathrm{M}) / \mathrm{KCl}(0.1 \mathrm{M})$ was used as the reference electrode and a platinum sheet $(2$ $\mathrm{cm}^{2}$ ) as the counter electrode. Cycles were carried out from -800 to $1200 \mathrm{mV}$ at a scan rate of $100 \mathrm{mV} \cdot \mathrm{s}^{-1}$ in $10^{-4} \mathrm{M}$ catechol in $0.01 \mathrm{M}$ phosphate buffer ( $\left.\mathrm{pH} 7.00\right)$. Experiments 
focused on studying of the effect of the scan rate were carried out from 10 to 1000 $\mathrm{mV} \cdot \mathrm{s}^{-1}$. Chronoamperometry was carried out at a fixed potential of $-200 \mathrm{mV}$.

\section{RESULTS AND DISCUSSION}

\subsection{Preparation and structural characterization of LbL films}

Films formed by the combination of $\mathrm{CHI}^{(+)}, \mathrm{IL}^{(+)}$and $\mathrm{CuPc}^{\mathrm{S}(-)}$ were deposited using the LbL technique. These films were used as substrates for enzyme immobilization and to promote electron transfer. Two types of structures were prepared: LbL films where cationic species were deposited in successive steps $\left[\mathrm{CHI}^{(+)}\left|\mathrm{CuPc}^{\mathrm{S}(-)}\right| \mathrm{IL}^{(+)} \mid\right.$ $\left.\mathrm{CuPc}^{\mathrm{S}(-)}\right]_{\mathrm{n}}$ and films where cations were mixed and deposited in a single step $\left[\mathrm{CHI}^{(+)}\right.$ $\left.+\mathrm{IL}^{(+)} \mid \mathrm{CuPc}^{\mathrm{S}(-)}\right]_{\mathrm{n}}$. The deposition of the layers was monitored by UV-vis spectroscopy (Figure 1.a). Spectra registered on quartz substrates were similar for all the films obtained, independently of their architecture. They showed the classical strong $\mathrm{Q}$ band at $680 \mathrm{~nm}$, originated by a $* \pi-\pi$ transition at the phthalocyanine ring. The $\mathrm{Q}$ band showed a shoulder at $617 \mathrm{~nm}$ associated to the presence of $H$-aggregates due to the formation of dimeric species [37,38]. Spectra also showed a band at $\sim 335 \mathrm{~nm}$ produced by a $* \pi-\pi$ transition named the Soret band [39]. As observed in Figure 1.b, absorbance values measured at $680 \mathrm{~nm}$ increased linearly with the number of layers (correlation coefficient higher than 0.9906 in all structures tested), confirming the formation of the layers on the surface of the substrate. Once LbL films had been obtained, Laccase was immobilized on the surface. UV-vis spectra of the $\left[\mathrm{CHI}^{(+)}\left|\mathrm{CuPc}^{\mathrm{S}(-)}\right| \mathrm{IL}^{(+)} \mid \mathrm{CuPc}^{\mathrm{S}(-)}\right]_{2}$ substrate and the $\left[\mathrm{CHI}^{(+)}\left|\mathrm{CuPc}^{\mathrm{S}(-)}\right| \mathrm{IL}^{(+)} \mid \mathrm{CuPc}^{\mathrm{S}(-)}\right]_{2} \mid \mathrm{Lac}$ biosensor are shown in Figure 1.c. The spectrum of the biosensor showed the characteristic bands of the LbL films and the typical band at $280 \mathrm{~nm}$ produced by the presence of the enzyme. Spectral data of $\left[\mathrm{CHI}^{(+)}+\mathrm{IL}^{(+)} \mid\right.$ $\left.\mathrm{CuPc}^{\mathrm{S}(-)}\right|_{2}$ and $\left[\mathrm{CHI}^{(+)}+\mathrm{IL}^{(+)}\left|\mathrm{CuPc}^{\mathrm{S}(-)}\right|_{2} \mid \mathrm{Lac}\right.$ are shown in Figure S.1, confirming the formation of the films on the surface of the substrate, independently of the sensor architecture. 


\section{"Here Figure 1"}

FTIR spectra of the LbL films, deposited on a zinc sulfide ( $\mathrm{ZnS}$ ) substrate, showed the characteristics bands of all three compounds forming the layers (Figure 2.a)[22,4042]. In addition, FTIR spectra were identical, regardless of the structure of the LbL films as can be seen in Figure S.2. The peaks of the $\left[\mathrm{CHI}^{(+)}+\mathrm{IL}^{(+)} \mid \mathrm{CuPc}^{(-)}\right]_{\mathrm{n}}$ sensor and casted films of the individual components are collected in Table 1.

The characteristic peaks of $\mathrm{CHH}$ appeared at $3424 \mathrm{~cm}$ corresponding to the $\mathrm{OH}$ stretching vibrations; at $1657 \mathrm{~cm}^{-1}$, related to the C-O stretching; and at $1419 \mathrm{~cm}^{-1}$ and $1395 \mathrm{~cm}^{-1}$, due to the $\mathrm{C}-\mathrm{H}-\mathrm{OH}$ bending and $6 \mathrm{OH}$ stretching, respectively. Peaks produced by the $\mathrm{IL}^{(+)}$appeared at $1647 \mathrm{~cm}^{-1}$, corresponding to the $\mathrm{C}=\mathrm{C}$ and $\mathrm{C}=\mathrm{N}$ bonds $[22,43,44]$. Peaks characteristic of the Cưpcappeared at $1456 \mathrm{~cm}^{-1}$ (asymmetric bending isoindole), $1338 \mathrm{~cm}$ (pyrrole stretching of the $-\mathrm{C}=\mathrm{C}-\mathrm{N}-$ bonds) [45-47], $1093 \mathrm{~cm}^{-1}$ produced by the in-plane $\mathrm{C}-\mathrm{H}$ bending, 1027 chrelated to the isoindole deformation and aza stretching [46], and $742 \mathrm{~cm}^{-1}$ due to $\mathrm{C}-\mathrm{H}$ bending $[46,48]$. Transmittance increased linearly with the number of layers, with regression coefficients close to 1 (for instance, the $\mathrm{R}^{2}$ of the peak at $1027 \mathrm{~cm}^{-1}$ was 0.9627 ). Similar coefficients were obtained for films with different architectures. The FTIR spectra of the biosensors were also registered. As expected, these spectra showed the typical amide bands of the polyphenol oxidase, which appeared at $1625 \mathrm{~cm}^{-1}$ and $1567 \mathrm{~cm}^{-1}$ (Figure 2.b). The band assignment confirmed the correct adsorption of the enzyme onto the surface of the LbL films [49].

\section{"Here Figure 2"}

\section{"Here Table 1"}


AFM images of the surface of films with different architectures and increasing number of layers were registered and compared (Figure 3). In all cases, the images showed smooth surfaces that increased their roughness when the number of layers were increased. The $\mathrm{RMS}$ of $\left[\mathrm{CHI}^{(+)}+\mathrm{IL}^{(+)} \mid \mathrm{CuPc}^{\mathrm{S}(-)}\right]_{2}$ (where both cationic species were mixed and deposited in the same step) was $0.39 \mathrm{~nm}$ and increased to $7.71 \mathrm{~nm}$ in thicker films formed by 12 bilayers $\left[\mathrm{CHI}^{(+)}+\mathrm{IL}^{(+)} \mid \mathrm{CuPc}^{\mathrm{S}(-)}\right]_{12}$. In $\mathrm{LbL}$ films where each cation was deposited in a different step, the RMS increased from 0.46 $\mathrm{nm}$ in $\left[\mathrm{CHI}^{(+)}\left|\mathrm{CuPc}^{\mathrm{S}(-)}\right| \mathrm{IL}^{(+)} \mid \mathrm{CuPc}^{\mathrm{S}(-)}\right]_{2}$ to 14.07 in $\left[\mathrm{CHI}^{(+)}\left|\mathrm{CuPc}^{\mathrm{S}(-)}\right| \mathrm{IL}^{(+)} \mid \mathrm{CuPc}^{\mathrm{S}(-)}\right]_{12}$. The increase in the RMS points to the presence of aggregation and indicates that the molecular ordering of the LbL films decreased with the number of layers. It is also important to point out that the different components added in sequential steps probably interpenetrate.

Figure 3.e shows the AFM image of the $\left[\mathrm{CHI}^{(+)}+\mathrm{IL}^{(+)} \mid \mathrm{CuPc}^{\mathrm{S}(-)}\right]_{2} \mid \mathrm{Lac}$ sensor. In the presence of the enzyme, globular structures were observed (138 nm height) on top of smooth surface ( $3 \mathrm{~nm}$ in height). These structures, with similar sizes, have been already observed in previously published results [8]. However, the presence of globules can be caused by the reorganization of the layer when laccase is deposited on top of the LbL film

“Her:e.Fsguring”properties of LbL films and biosensors based on LbL films

The sensing properties for catechol of $\left[\mathrm{CHI}^{(+)}+\mathrm{IL}^{(+)} \mid \mathrm{CuPc}^{\mathrm{S}(-)}\right]_{\mathrm{n}}$ and $\left[\mathrm{CHI}^{(+)} \mid\right.$ $\left.\mathrm{CuPc}^{(-)}\left|\mathrm{IL}^{(+)}\right| \mathrm{CuPc}^{\mathrm{S}(-)}\right]_{\mathrm{n}} \quad$ films were analyzed by cyclic voltammetry. Then, laccase was deposited on top of LbL films and the performance of the biosensors was analyzed.

A bare ITO, immersed in catechol $10^{-4} \mathrm{M}$, showed one anodic wave at $\sim 900 \mathrm{mV}$ and one cathodic wave at $\sim 100 \mathrm{mV}$, corresponding to the oxidation and reduction of catechol, respectively. When the ITO was modified with the LbL films, the intensity of 
the peaks increased (for instance, the intensity of the cathodic peak increased from -5 to $-12 \mu \mathrm{A})$, indicating a certain electrocatalytic activity of the LbL films. It is worth noting that the results obtained were similar, independently of the number of layers, confirming that the electrocatalysis was a surface phenomenon (Figure S.3). Moreover, the chemical nature of the last layer was fundamental to obtain good responses and only when the last layer was formed by $\mathrm{CuPc}^{\mathrm{S}(-)}$ was electrocatalytic behavior observed.

The presence of the enzyme considerably increased the intensity of the cathodic wave (from $-12 \mu \mathrm{A}-33 \mu \mathrm{A}$ ). This was due to the increase in the efficiency of the electrontransfer between the enzyme and the electrode, activated by the presence of the LbL films. This effect was clearly observed when the $\mathrm{CuPc}^{\mathrm{S}(-)}$ was in direct contact with laccase. In contrast, when the last layer was the positively charged $\mathrm{CHI}^{(+)}+\mathrm{IL}^{(+)}$mixture, the intensity of the cathodic wave was only $16 \mu \mathrm{A}$ (Figure 4), or $17.5 \mu \mathrm{A}$ when the last layer was $\mathrm{CHI}^{(+)}$. According to the previous results, ideal substrates must have $\mathrm{CuPc}^{\mathrm{S}(-)}$ as the top layer, while structure and thickness are irrelevant. For these reasons, the rest of the study was carried out using only the $\left[\mathrm{CHI}^{(+)}+\mathrm{IL}^{(+)} \mid \mathrm{CuPc}^{\mathrm{S}(-)}\right]_{2}$ substrate. Figure S.4 shows the voltammograms registered using bare ITO and an ITO covered with laccase.

\section{"Here Figure 4"}

The repeatability of the measurements was tested by calculating the coefficients of variation in the intensity of the cathodic peaks for 10 consecutive cycles (Figure S.5). The coefficient of variation was $2.0 \%$ for $\left[\mathrm{CHI}^{(+)}+\mathrm{IL}^{(+)} \mid \mathrm{CuPc}^{\mathrm{(}(-)}\right]_{2}$ and $4.6 \%$ for $\left[\mathrm{CHI}^{(+)}\left|\mathrm{CuPc}^{\mathrm{S}(-)}\right| \mathrm{IL}^{(+)} \mid \mathrm{CuPc}^{\mathrm{S}(-)}\right]_{2}$. Thus, the best repeatability $\left[\mathrm{CHI}^{(+)}+\mathrm{IL}^{(+)} \mid \mathrm{CuPc}^{\mathrm{S}(-)}\right]_{2}$ sensor was selected as the underlying layer for the laccase biosensor.

The repeatability of the $\left[\mathrm{CHI}^{(+)}+\mathrm{IL}^{(+)} \mid \mathrm{CuPc}^{\mathrm{S}(-)}\right]_{2} \mid \mathrm{Lac}$ biosensor, calculated from the intensity values registered after 10 consecutive cycles, was $4.7 \%$. This indicated that the 
biosensors could be repeatedly cycled without considerable loss of intensity. However, once the sensors were withdrawn from the solution, a decrease in the intensity of the peaks was perceived and biosensors were considered as disposable devices.

The variation coefficients of the responses of 3 sensors, prepared under the same conditions, were $3.8 \%$ for the $\left[\mathrm{CHI}^{(+)}+\mathrm{IL}^{(+)} \mid \mathrm{CuPc}^{\mathrm{S}(-)}\right]_{2}$ architecture $(-12 \pm 0.46 \mu \mathrm{A}(\mathrm{n}=3)$ and $4.1 \%$ for the $\left[\mathrm{CHI}^{(+)}+\mathrm{IL}^{(+)} \mid \mathrm{CuPc}^{\mathrm{S}(-)}\right]_{2} \mid \mathrm{Lac}$ biosensor $(-33 \pm 1.4 \mu \mathrm{A}(\mathrm{n}=3))$, indicating the good level of accuracy achieved in the fabrication of the developed enzymatic electrochemical biosensor (Figure S.6).

\subsubsection{Effect of scan rate}

Information about the electrochemical mechanisms can be obtained from the analysis of the relationship between the peak current and the scan rate. The voltammetric behavior of sensors and biosensors immersed in catechol $\left(10^{-4} \mathrm{M}\right.$ in $0.01 \mathrm{M}$ phosphate buffer $\mathrm{pH}$ 7.00) at different scan rates was studied (from 10 to $1000 \mathrm{mV} \cdot \mathrm{s}^{-1}$ ), as shown in Figure 5.

\section{"Here Figure 5"}

The peak potential of the reduction peak shifted to more negative potential values when the scan rate increased, confirming the irreversibility of the process. The linear relationship between the peak potential and the logarithm of the scan rate can be expressed as (1) for the $\left[\mathrm{CHI}^{(+)}+\mathrm{IL}^{(+)} \mid \mathrm{CuPc}^{\mathrm{S}(-)}\right]_{2}$ sensor and (2) for the $\left[\mathrm{CHI}^{(+)}+\mathrm{IL}^{(+)} \mid \mathrm{CuPc}^{\mathrm{S}(-)}\right]_{2} \mid$ Lac biosensor (shown in Figures S.7.a and .b, respectively).

$$
\begin{aligned}
& \mathrm{E}_{p c}(V)=-0.12 \log v\left(V s^{-1}\right)-0.44 ; \quad\left(R^{2}=0.9432\right) \\
& E_{p c}(V)=-0.10 \log v\left(V s^{-1}\right)-0.45 ; \quad\left(R^{2}=0.9238\right)
\end{aligned}
$$

As for an irreversible electrode process, according to Laviron [51], the Epc is defined by the following equation: 


$$
E_{p c}(V)=E^{0^{\prime}}+\left(\frac{2.303 R T}{\propto n F}\right) \log \left(\frac{R T k^{0}}{\propto n F}\right)-\left(\frac{2.303 R T}{\propto n F}\right) \log v\left(V s^{-1}\right)
$$

where $\alpha$ is the transfer coefficient, $\mathrm{k}^{0}$ the standard heterogeneous rate constant of the reaction, $\mathrm{n}$ the number of electrons transferred, $\mathrm{v}$ the scan rate, $\mathrm{R}$ the ideal gas constant $\left(8,314 \mathrm{~J} \cdot \mathrm{mol}^{-1} \cdot \mathrm{K}^{-1}\right), \mathrm{T}$ the temperature $(298 \mathrm{~K}), \mathrm{F}$ Faraday's constant $\left(96,480 \mathrm{C} \cdot \mathrm{mol}^{-1}\right)$ and $\mathrm{E}^{0}$ ' the formal redox potential. Therefore, the value $\alpha$ can easily be calculated from the slope of $\mathrm{E}_{\mathrm{pc}}$ vs. $\log \mathrm{v}$, which was calculated to be 0.47 when using a $\left[\mathrm{CHI}^{(+)}+\mathrm{IL}^{(+)} \mid\right.$ $\left.\mathrm{CuPc}^{\mathrm{S}(-)}\right]_{2}$ electrode and 0.55 for the enzymatic electrode. Furthermore, according to the Butler-Volmer equation, the $\alpha$ value can be calculated [52,53]. For large values of the overpotential $(\eta>118 \mathrm{mV})$, the Butler-Volmequation can be simplified as follows:

$$
\log I_{p c}(\mu A)=\log I_{0}-\frac{\alpha F}{2.3 R T} \eta
$$

The value of $\alpha$ can be estimated from the slope of the Tafel plot (known as the plot of $\log \mathrm{I}_{\mathrm{pc}}$ vs. $\left.\eta\right)$. Therefore, the value calculated for $\alpha$ was 0.23 for the $\left[\mathrm{CHI}^{(+)}+\mathrm{IL}^{(+)}\right.$ $\left.\mathrm{CuPc}^{\mathrm{S}(-)}\right]_{2}$ sensor and 0.25 for the $\left[\mathrm{CHI}^{(+)}+\mathrm{IL}^{(+)} \mid \mathrm{CuPc}^{\mathrm{S}(-)}\right]_{2} \mid \mathrm{Lac}$ biosensor. Thus, the electron transfer number of $\mathrm{n}$ was found to be between 2.1-2.2, which is in accordance with a two-electron process in all electrodes (Figure S.8).

\subsubsection{Effect of the catechol concentration}

The limits of detection (LOD) were calculated, using chronoamperometry (CA), by analyzing the intensity of the responses to increasing concentrations of catechol obtained by the successive addition of aliquots of catechol every $100 \mathrm{~s}$ (in $0.01 \mathrm{M}$ phosphate buffer $\mathrm{pH} 7.00$ ). The potential used was $-200 \mathrm{mV}$.

\section{"Here Figure 6"}


As observed in Figure 6, the sensor $(\mathrm{n}=3)\left[\mathrm{CHI}^{(+)}+\mathrm{IL}^{(+)} \mid \mathrm{CuPc}^{\mathrm{S}(-)}\right]_{2}$ and the biosensor $(\mathrm{n}=3) \quad\left[\mathrm{CHI}^{(+)}+\mathrm{IL}^{(+)} \mid \mathrm{CuPc}^{\mathrm{S}(-)}\right]_{2} \mid \mathrm{Lac}$ both showed linear responses in the range from 2.4-38 $\mu \mathrm{M}$ and 2.4-26 $\mu \mathrm{M}$, respectively, with linear equations of $I_{p c}(\mu \mathrm{A})=(-4.38 \pm 0.01)$ $(0.070 \pm 0.001) \cdot[$ catechol $] / \mu \mathrm{A} \cdot \mu \mathrm{M} \quad\left(\mathrm{R}^{2}=0.993\right)$ for the non-biosensor and $I_{p c}(\mu \mathrm{A})$ $=(-10.020 \pm 0.005)-(0.237 \pm 0.001) \cdot[$ catechol $] / \mu \mathrm{A} \mu \mathrm{M}\left(\mathrm{R}^{2}=0.997\right)$ for the biosensor. The electrocatalytic behavior of the modified electrodes at different concentrations of catechol confirmed that the biosensor was more effective than the sensor, with better sensitivity to the reduction of catechol in $0.01 \mathrm{M}$ phosphate buffer $\mathrm{pH} 7.00$.

The LODs were calculated from the linear range of the calibration curves registered in the reduction region, using the $3 \cdot \sigma / \mathrm{m}$ criterion, where $\sigma$ is the standard deviation for 5 voltammograms of blank solutions and $\mathrm{m}$ is the slope of the calibration plot.

The LbL sensor showed a sensitivity of $0.07 \mathrm{~A} \cdot \mathrm{M}^{-1}$, a detection limit of $2.17 \cdot 10^{-8} \mathrm{M}$ and a linear detection range from $2.4 \mu \mathrm{M}$ to $38 \mu \mathrm{M}$. The LOD obtained for the LbL biosensor was lower and a detection limit of $8.96 \cdot 10^{-10} \mathrm{M}$, with a sensitivity of 0.24 $\mathrm{A} \cdot \mathrm{M}^{-1}$ and linear detection range from $2.4 \mu \mathrm{M}$ to $26 \mu \mathrm{M}$, were obtained.

The apparent Michaelis-Menten constant $\left(K_{M p}^{a p p}\right)$ was obtained through the linearization of the Lineweaver-Burk equation from both intensity regions.

$$
\frac{1}{I}=\frac{1}{I_{\max }}+\frac{K_{M}^{a p p}}{I_{\max } \cdot[S]}
$$

where $\mathrm{I}$ is the intensity of the cathodic current after $100 \mathrm{~s}$ of analyte addition, $\mathrm{I}_{\max }$ is the maximum rate of the enzymatic reaction and $[\mathrm{S}]$ is the concentration of substrate. The $\mathrm{I}_{\max }$ and the $K_{M}^{a p p}$ were calculated from the intercept and the slope, respectively [54]. The small value $\boldsymbol{K f}^{\text {app }}$ abtained with the developed nanostructured biosensor, indicated excellent affinity between the laccase and the substrate. 


\section{"Here Table 2"}

Table 2 shows the analytical parameters characteristic of the new enzymatic biosensor developed here. The Table also shows some previous results obtained with different electrochemical biosensors with laccase immobilized in different matrices for catechol detection, including biomimetic matrices (LbL, SAM and Langmuir-Blodgett). The comparison with these previous results, and others collected in a recent review [55], corroborate the excellent performance of our biosensor, where the LOD of the developed biosensor $\left(8.96 \cdot 10^{-10} \mathrm{M}\right)$ has significantly improved the LOD for catechol.

\section{CONCLUSIONS}

A new strategy to obtain efficient substrates for laccase-based biosensors for the detection of catechol has been developed. Using the LbL technique, thin layers combining materials with complementary functionalities have been obtained. It has been demonstrated that LbL composite films combining an efficient electron mediator (such as a copper phthalocyanine derivative), an ionic liquid that increases the conductivity of the films (1-butyl-3-methylimidazolium tetrafluoroborate) and chitosan (which interacts efficiently with enzymes), provide a suitable support for laccase immobilization.

Biosensors with laccase immobilized on the LbL layers have shown a detection limit of $8.96 \cdot 10^{-10} \mathrm{M}$ towards catechol, confirming the high efficiency of the substrate, reaching detection limits lower than those reported in the bibliography.

This technique has allowed us to develop LbL substrates that, at the same time, act as an efficient support for enzyme immobilization and successful electron transfer layers.

\section{ACKNOWLEDGMENTS}


We appreciate the financial support of MINECO-FEDER (AGL2015-67482-R and RTI2018_097990-B-100) and Junta de Castilla y Leon and FEDER (VA275P18). The authors would also like to thank Prof. Javier Martinez Rodrigo for helping with the AFM measurements. 


\section{REFERENCES}

[1] J.H. Tyman, Synthetic and Natural Phenols, First, Elsevier Science, 1996.

[2] F. Karim A. N. M. Fakhruddin, Recent advances in the development of biosensor for phenol: a review, Rev Environ Sci Biotechnol 11 (2012) 261-274. doi: $10.1007 / \mathrm{s} 11157-012-9268-9$

[3] W. Jina, G. Maduraiveeran, Electrochemical detection of chemical pollutants based on gold nanomaterials, Trends Environ. Anal. 14 (2017) 28-36. doi: 10.1016/j.teac.2017.05.001

[4] P. Alessio, F.J. Pavinatto, O.N. Oliveira Jr, J.A. De Saja Saez, C.J.L. Constantino, M.L. Rodríguez-Méndez, Detection of catechol using mixed Langmuir-Blodgett films of a phospholipid and phthalocyanines as voltammetric sensors, Analyst. 135 (2010) 2591. doi:10.1039/c0an00159g.

[5] F. Dridi, M. Marrakchi, M. Gargouri, J. Saulnier, N. Jaffrezic-Renault, F. Lagarde, Nanomaterial-based electrochemical biosensors for food safety and quality assessment. Nanobiosensors, pp.167-204. Elsevier: The Netherlands, 2017. doi:10.1016/B978-0-12-804301-1.00005-9.

[6] W. Putzbach, N.J. Ronkainen, Immobilization techniques in the fabrication of nanomaterial-based electrochemical biosensors: A review, Sensors (Switzerland). 13 (2013) 4811-4840. doi:10.3390/s130404811.

[7] T.M.B.F. Oliveira, M. Fátima Barroso, S. Morais, M. Araújo, C. Freire, P. de Lima-Neto, A.N. Correia, M.B.P.P. Oliveira, C. Delerue-Matos, LaccasePrussian blue film-graphene doped carbon paste modified electrode for carbamate pesticides quantification, Biosens. Bioelectron. 47 (2013) 292-299. 
doi:10.1016/j.bios.2013.03.026.

[8] M. Nazari, S. Kashanian, R. Rafipour, Laccase immobilization on the electrode surface to design a biosensor for the detection of phenolic compound such as catechol, Spectrochim. Acta - Part A Mol. Biomol. Spectrosc. 145 (2015) 130138. doi:10.1016/j.saa.2015.01.126.

[9] C. Apetrei, M.L. Rodríguez-Méndez, J.A. De Saja, Amperometric tyrosinase based biosensor using an electropolymerized phosphate-doped polypyrrole film as an immobilization support. Application for detection of phenolic compounds, Electrochim. Acta. 56 (2011) 8919-8925. doi:10.1016/j.electacta.2011.07.127.

[10] Y. Zheng, D. Wang, Z. Li, X. Sun, T. Gao, G. Zhou, Laccase biosensor fabricated on flower-shaped yolk-shell $\mathrm{SiO} 2$ nanospheres for catechol detection, Colloids Surfaces A Physicochem. Eng. Asp. 538 (2018) 202-209. doi:10.1016/j.colsurfa.2017.10.086.

[11] Y.Q. Zhang, Y.J. Fan, L. Cheng, L.L. Fan, Z.Y. Wang, J.P. Zhong, L.N. Wu, X.C. Shen, Z.J. Shi, A novel glucose biosensor based on the immobilization of glucose oxidase on layer-by-layer assembly film of copper phthalocyanine functionalized graphene, Electrochim. Acta. 104 (2013) 178-184. doi:10.1016/j.electacta.2013.04.099.

[12] M. Zhang, A. Halder, C. Hou, J. Ulstrup, Q. Chi, Free-standing and flexible graphene papers as disposable non-enzymatic electrochemical sensors, Bioelectrochemistry. 109 (2016) 87-94. doi:10.1016/j.bioelechem.2016.02.002.

[13] R.A. de Sousa Luza, M.V.A. Martinsa, J.L. Magalhãesa, J.R. Siqueira Jr., V. Zucolottoc, O.N. Oliveira Jr., F.N. Crespilho, W.C da Silva. Supramolecular architectures in layer-by-layer films of single-walled carbon nanotubes, chitosan 
and cobalt (II) phthalocyanine. Mat. Chem 130 (2011) 1072-1077. doi: 10.1016/j.matchemphys.2011.08.038

[14] P. Alessio, C.S. Martin, J.A. De Saja, M.L. Rodriguez-Mendez, Mimetic biosensors composed by layer-by-layer films of phospholipid, phthalocyanine and silver nanoparticles to polyphenol detection, Sensors Actuators, B Chem. 233 (2016) 654-666. doi:10.1016/j.snb.2016.04.139.

[15] J.R. Siqueira, Jr., L.H.S. Gasparotto, F.N. Crespilho, A.J.F. Carvalho,V. Zucolotto, O.N. Oliveira, Jr. Physicochemical Properties and Sensing Ability of Metallophthalocyanines/Chitosan Nanocomposites. J. Phys. Chem. B 110 (2006) 22690-22694. doi: 10.1021/jp0649089.

[16] J.S. Graça, R.F. de Oliveira, M.L. de Moraes, M. Ferreira, Amperometric glucose biosensor based on layer-by-layer films of microperoxidase-11 and liposomeencapsulated glucose oxidase, Bioelectrochemistry. $96 \quad$ (2014) 37-42. doi:10.1016/j.bioelechem.2014.01.001.

[17] E.G.R. Fernandes, L.C. Brazaca, M.L. Rodríguez-Mendez, J.A. de Saja, V. Zucolotto, Immobilization of lutetium bisphthalocyanine in nanostructured biomimetic sensors using the LbL technique for phenol detection, Biosens. Bioelectron. 26 (2011) 4715-4719. doi:10.1016/j.bios.2011.05.032.

[18] F.N. Crespilho, M.E. Ghica, V. Zucolotto, F.C. Nart, O.N. Oliveira, C.M.A. Brett, Electroactive nanostructured membranes (ENM): Synthesis and electrochemical properties of redox mediator-modified gold nanoparticles using a dendrimer layer-by-layer approach, Electroanalysis. 19 (2007) 805-812. doi:10.1002/elan.200603775.

[19] E. Aynaci, A. Yaşar, F. Arslan, An amperometric biosensor for acetylcholine 
determination prepared from acetylcholinesterase-choline oxidase immobilized in polypyrrole- polyvinylsulpfonate film, Sensors Actuators, B Chem. 202 (2014) 1028-1036. doi:10.1016/j.snb.2014.06.049.

[20] Y. Tan, W. Deng, C. Chen, Q. Xie, L. Lei, Y. Li, Z. Fang, M. Ma, J. Chen, S. Yao, Immobilization of enzymes at high load/activity by aqueous electrodeposition of enzyme-tethered chitosan for highly sensitive amperometric biosensing, Biosens. Bioelectron. $25 \quad$ (2010) 2644-2650. doi:10.1016/j.bios.2010.04.040.

[21] X. Lu, J. Hu, X. Yao, Z. Wang, J. Li, Composite system based on chitosan and room-temperature ionic liquid: Direct electrochemistry and electrocatalysis of hemoglobin, Biomacromolecules. 7 (2006) 975-980. doi:10.1021/bm050933t.

[22] S. Yasmeen, M. Kabiraz, B. Saha, M. Qadir, M. Gafur, S. Masum, Chromium (VI) Ions Removal from Tannery Effluent using Chitosan-Microcrystalline Cellulose Composite as Adsorbent, Int. Res. J. Pure Appl. Chem. 10 (2016) 1-14. doi:10.9734/IRJPAC/2016/23315.

[23] R.D. Koyani, R. Vazquez-Duhalt, Laccase encapsulation in chitosan nanoparticles enhances the protein stability against microbial degradation, Environ. Sci. Pollut. Res. 23 (2016) 18850-18857. doi:10.1007/s11356-016$7072-8$.

[24] H. Cabana, A. Ahamed, R. Leduc, Conjugation of Laccase from the white rot fungus Trametes versicolor to chitosan and its utilization for the elimination of triclosan, Bioresour. Technol. $102 \quad$ (2011) 1656-1662. doi:10.1016/j.biortech.2010.09.080.

[25] L. Yang, H. Xiong, X. Zhang, S. Wang, A novel tyrosinase biosensor based on 
chitosan-carbon-coated nickel nanocomposite film, Bioelectrochemistry. 84 (2012) 44-48. doi:10.1016/j.bioelechem.2011.11.001.

[26] S. Chaiyo, E. Mehmeti, W. Siangproh, T.L. Hoang, H.P. Nguyen, O. Chailapakul, K. Kalcher, Non-enzymatic electrochemical detection of glucose with a disposable paper-based sensor using a cobalt phthalocyanine-ionic liquidgraphene composite, Biosens. Bioelectron. 102 (2018) 113-120. doi:10.1016/j.bios.2017.11.015.

[27] I. Zahou, R. Mlika, H. BenOuada, R. BenChaabane, N. Jaffrezic-Renault, Studies on the electrochemical properties of nickel phtalocyanine for impedimetric detection of environment pollutants: hydroquinone and bisphenol A, IET Sci. Meas. Technol. 9 (2015) 315-321. doi:10.1049/iet-smt.2014.0027.

[28] R. Gonzalez-Anton, M.M. Osipova, C. Garcia-Hernandez, T. V. Dubinina, L.G. Tomilova, C. Garcia-Cabezon, M.L. Rodriguez-Mendez, Subphthalocyanines as electron mediators in biosensors based on phenol oxidases: Application to the analysis of red wines, Electrochim. Acta. 255 (2017) 239-247. doi:10.1016/j.electacta.2017.09.168.

[29] R. Devasenathipathy, C. Karuppiah, S.-M. Chen, S. Palanisamy, B.-S. Lou, M.A. Ali, F.M.A. Al-Hemaid, A sensitive and selective enzyme-free amperometric glucose biosensor using a composite from multi-walled carbon nanotubes and cobalt phthalocyanine, RSC Adv. 5 (2015) 26762-26768. doi:10.1039/C4RA17161F.

[30] C. Medina-Plaza, G. Revilla, R. Muñoz, J.A. Fernández-Escudero, E. Barajas, G. Medrano, J.A. de Saja, M.L. Rodriguez-Mendez, Electronic tongue formed by sensors and biosensors containing phthalocyanines as electron mediators: 
Application to the analysis of red grapes, J. Porphyr. Phthalocyanines. 18 (2014) 76-86. doi:10.1142/S1088424613501137.

[31] C. Garcia-Hernandez, C. Salvo Comino, F. Martín-Pedrosa, M.L. RodriguezMendez, C. Garcia-Cabezon, Impedimetric electronic tongue based on nanocomposites for the analysis of red wines. Improving the variable selection method, Sensors Actuators, B Chem. $277 \quad$ (2018) 365-372. doi:10.1016/j.snb.2018.09.023.

[32] L. Cui, T. Pu, Y. Liu, X. He, Layer-by-layer construction of graphene/cobalt phthalocyanine composite film on activated GCE for application as a nitrite sensor, Electrochim. Acta. $88 \quad$ (2013) 559-564. doi:10.1016/j.electacta.2012.10.127.

[33] V. V. Singh, A.K. Nigam, A. Batra, M. Boopathi, B. Singh, R. Vijayaraghavan, Applications of Ionic Liquids in Electrochemical Sensors and Biosensors, Int. J. Electrochem. 2012 (2012) 1-19. doi:10.1155/2012/165683.

[34] S. Liu, Hao; Wu, Xing; Sun, Jianliang; Chen, Stimulation of Laccase Biocatalysis in Ionic Liquids: A Review on Recent Progress, Curr. Protein Pept. Sci. 19 (2018) 100-111.

[35] J. Hong, Y.X. Zhao, B.L. Xiao, A.A. Moosavi-Movahedi, H. Ghourchian, N. Sheibani, Direct electrochemistry of hemoglobin immobilized on a functionalized multi-walled carbon nanotubes and gold nanoparticles nanocomplex-modified glassy carbon electrode, Sensors (Switzerland). 13 (2013) 8595-8611. doi:10.3390/s130708595.

[36] J.Y. Sun, K.J. Huang, S.F. Zhao, Y. Fan, Z.W. Wu, Direct electrochemistry and electrocatalysis of hemoglobin on chitosan-room temperature ionic liquid-TiO2- 
graphene nanocomposite film modified electrode, Bioelectrochemistry. 82 (2011) 125-130. doi:10.1016/j.bioelechem.2011.06.007.

[37] J.Q. Zeng, S.N. Sun, J.P. Zhong, X.F. Li, R.X. Wang, L.N. Wu, L. Wang, Y.J. Fan, Pd nanoparticles supported on copper phthalocyanine functionalized carbon nanotubes for enhanced formic acid electrooxidation, Int. J. Hydrogen Energy. 39 (2014) 15928-15936. doi:10.1016/j.ijhydene.2014.04.048.

[38] R.A. Hatton, N.P. Blanchard, V. Stolojan, A.J. Miller, S.R.P. Silva, Nanostructured copper phthalocyanine-sensitized multiwall carbon nanotube films, Langmuir. 23 (2007) 6424-6430. doi:10.1021/la070156d.

[39] Y. Wang, H.Z. Chen, H.Y. Li, M. Wang, Fabrication of carbon nanotubes/copper phthalocyanine composites with improved compatibility, Mater. Sci. Eng. B Solid-State Mater. Adv. Technol. $117 \quad$ (2005) 296-301. doi:10.1016/j.mseb.2004.12.007.

[40] R. Seoudi, G.S. El-Bahy, Z.A. El Sayed, FTIR, TGA and DC electrical conductivity studies of phthalocyanine and its complexes, J. Mol. Struct. 753 (2005) 119-126. doi:10.1016/j.molstruc.2005.06.003.

[41] Y. Jeon, J. Sung, D. Kim, C. Seo, H. Cheong, Y. Ouchi, R. Ozawa, H.O. Hamaguchi, Structural change of 1-butyl-3-methylimidazolium tetrafluoroborate + water mixtures studied by infrared vibrational spectroscopy, J. Phys. Chem. B. 112 (2008) 923-928. doi:10.1021/jp0746650.

[42] J. Souto, Y. Gorbunova, M.L. Rodriguez-Méndez, S. Kudrevich, J.E. Van Lier, J.A. De Saja, Langmuir-Blodgett film formation and spectroscopic characterization of sulphonated derivatives of zinc phthalocyanine, J. Raman Spectrosc. $27 \quad$ (1996) 649-655. doi:10.1002/(SICI)1097- 
4555(199609)27:9<649::AID-JRS9>3.0.CO;2-B.

[43] S.A. Dharaskar, K.L. Wasewar, M.N. Varma, D.Z. Shende, C.K. Yoo, Synthesis, characterization and application of 1-butyl-3-methylimidazolium tetrafluoroborate for extractive desulfurization of liquid fuel, Arab. J. Chem. 9 (2016) 578-587. doi:10.1016/j.arabjc.2013.09.034.

[44] V. Srinivasa Rao, T. Vijaya Krishna, T. Madhu Mohan, P. Madhusudana Rao, Thermodynamic and volumetric behavior of green solvent 1-butyl-3methylimidazolium tetrafluoroborate with aniline from $\mathrm{T}=(293.15$ to 323.15$) \mathrm{K}$ at atmospheric pressure, J. Chem. Thermodyn. 100 (2016) 165-176. doi:10.1016/j.jct.2016.04.024.

[45] M. Norman, J. Zdarta, P. Bartczak, A. Piasecki, I. Petrenko, H. Ehrlich, T. Jesionowski, Marine sponge skeleton photosensitized by copper phthalocyanine: A catalyst for Rhodamine B degradation, Open Chem. 14 (2016) 243-254. doi:10.1515/chem-2016-0025.

[46] F. Lu, M. Bao, C. Ma, X. Zhang, D.P. Arnold, J. Jiang, Infrared spectra of phthalocyanine and naphthalocyanine in sandwich-type (na)phthalocyaninato and porphyrinato rare earth complexes. Part 3. The effects of substituents and molecular symmetry on the infrared characteristics of phthalocyanine in bis(phthal, Spectrochim. Acta Part A Mol. Biomol. Spectrosc. 59 (2003) 32733286. doi:10.1016/S1386-1425(03)00158-6.

[47] L.S. Koodlur, Layer-by-layer self assembly of a water-soluble phthalocyanine on gold. Application to the electrochemical determination of hydrogen peroxide, Bioelectrochemistry. 91 (2013) 21-27. doi:10.1016/j.bioelechem.2012.12.001.

[48] L. Gaffo, C.J.L. Constantino, W.C. Moreira, R.F. Aroca, O.N. Oliveira, 
Vibrational spectra and surface-enhanced resonance Raman scattering of palladium phthalocyanine evaporated films, J. Raman Spectrosc. 33 (2002) 833837. doi:10.1002/jrs.924.

[49] M. Romero-arcos, M.G. Garnica-romo, H.E. Martínez-flores, Electrochemical Study and Characterization of an Amperometric Biosensor Based on the Immobilization of Laccase in a Nanostructure of TiO 2 Synthesized by the SolGel Method, (2016) 8-13. doi:10.3390/ma9070543.

[50] P.J. Yoo, K.T. Enam, J.F. Qi, S.K. Lee, J. Park , A.M. Belcher, P.T. Hammond, Spontaneous assembly of viruses on multilayered polymer surfaces, Nature Materials 5(2006) 234-240. doi: 10.1038/nmat1596.

[51] A.V. Straeten, A. Bratek-Skicki, A. M. Jonas, C.A. Fustin, C. DupontGillain, Integrating Proteins in Layer-by-Layer Assemblies Independently of their Electrical Charge. ACS Nano 12 (2018) 8372-838. doi: 10.1021/acsnano.8b03710.

[52] C. García-Hernández, C. García-Cabezón, F. Martín-Pedrosa, J.A. De Saja, M.L. Rodríguez-Méndez, Layered composites of PEDOT/PSS/nanoparticles and PEDOT/PSS/phthalocyanines as electron mediators for sensors and biosensors, Beilstein J. Nanotechnol. 7 (2016) 1948-1959. doi:10.3762/bjnano.7.186.

[53] J. Zhang, J. Xu, Y. Wen, Z. Wang, H. Zhang, W. Ding, Voltammetric determination of phytoinhibitor maleic hydrazide using PEDOT:PSS composite electrode, J. Electroanal. Chem. $751 \quad$ (2015) 65-74. doi:10.1016/j.jelechem.2015.05.032.

[54] C. Apetrei, J. Saja, J. Zurro, M. Rodríguez-Méndez, Advantages of the Biomimetic Nanostructured Films as an Immobilization Method vs. the Carbon 
Paste Classical Method, Catalysts. 2 (2012) 517-531. doi:10.3390/catal2040517.

[55] M.M. Rodríguez-Delgado, G.S. Alemán-Nava, J.M. Rodríguez-Delgado, G. Dieck-Assad, S.O. Martínez-Chapa, D. Barceló, R. Parra, Laccase-based biosensors for detection of phenolic compounds, Trends Anal. Chem. 74 (2015) 21-45. doi:10.1016/j.trac.2015.05.008.

[56] S. Sadeghi, E. Fooladi, A New Amperometric Biosensor Based on Fe 3 O 4 / Polyaniline / Laccase / Chitosan Biocomposite-Modified Carbon Paste Electrode for Determination of Catechol in Tea Leaves, (2015) 1603-1616. doi:10.1007/s12010-014-1380-6.

[57] X. Zhou, L. Liu, X. Bai, H. Shi, A reduced graphene oxide based biosensor for high-sensitive detection of phenols in water samples, Sensors Actuators B. Chem. 181 (2013) 661-667. doi:10.1016/j.snb.2013.02.021.

[58] Y. Li, L. Zhang, M. Li, Z. Pan, D. Li, A disposable biosensor based on immobilization of Laccase with silica spheres on the MWCNTs- doped screenprinted electrode, Chem. Cent. J. (2012) 2-9. 10.1186/1752-153X-6-103.

[59] R.S. Freire, N. Dura, L.T. Kubota, Effects of fungal Laccase immobilization procedures for the development of a biosensor for phenol compounds, 54 (2001) $681-686$.

[60] M.L. Antonelli, C. Tortolini, F. Mazzei, S. Cannistraro, C. Lanzellotto, G. Favero, E. Coppari, Nanostructured enzymatic biosensor based on fullerene and gold nanoparticles: Preparation, characterization and analytical applications, Biosens. Bioelectron. 55 (2013) 430-437. doi:10.1016/j.bios.2013.12.028.

[61] C. Medina-Plaza, J.A. de Saja, M.L. Rodriguez-Mendez, Bioelectronic tongue 
based on lipidic nanostructured layers containing phenol oxidases and lutetium bisphthalocyanine for the analysis of grapes, Biosens. Bioelectron. 57 (2014) 276-283. doi:10.1016/j.bios.2014.02.023.

[62] M. Romero-Arcos, M.G. Garnica-Romo, H.E. Martínez-Flores, Electrochemical Study and Characterization of an Amperometric Biosensor Based on the Immobilization of Laccase in a Nanostructure of TiO2 Synthesized by the SolGel Method, Materials 9 (2016) 543-555. doi:10.3390/ma9070543.

[63] Y. Pang, G.M. Zeng; L. Tang; Y. Zhang; Z. Li; L.J. CHemccase biosensor using magnetic multiwalled carbon nanotubes and chitosan/silica hybrid membrane modified magnetic carbon paste electrode, J. Cent. South Univ. Technol. 18 (2011) 1849-1856. doi: 10.1007/s11771-011-0913-1.é 

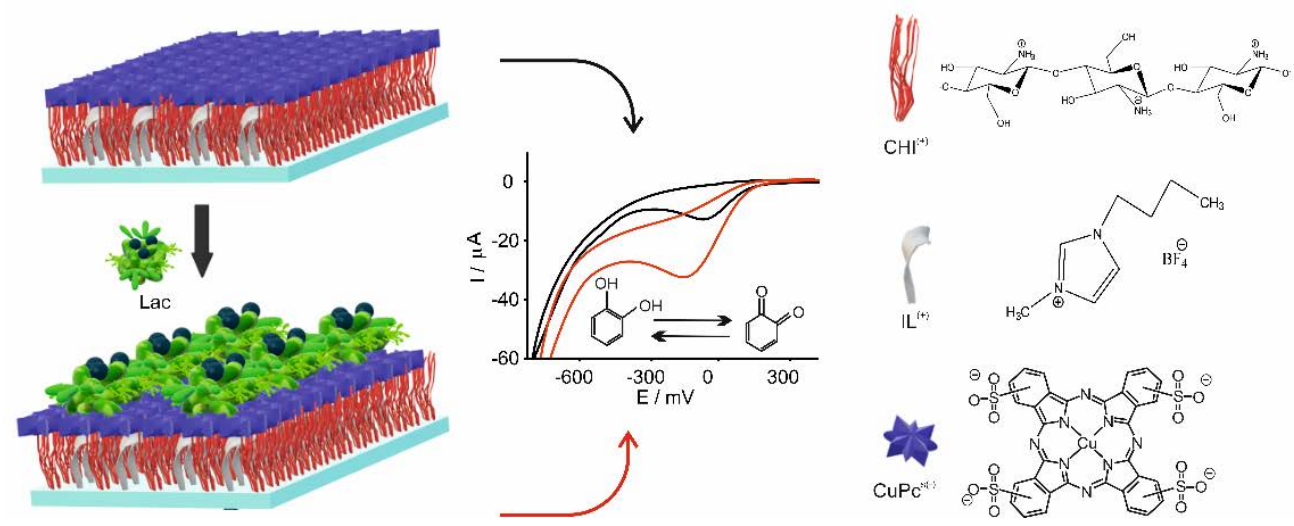

graphic abstract 

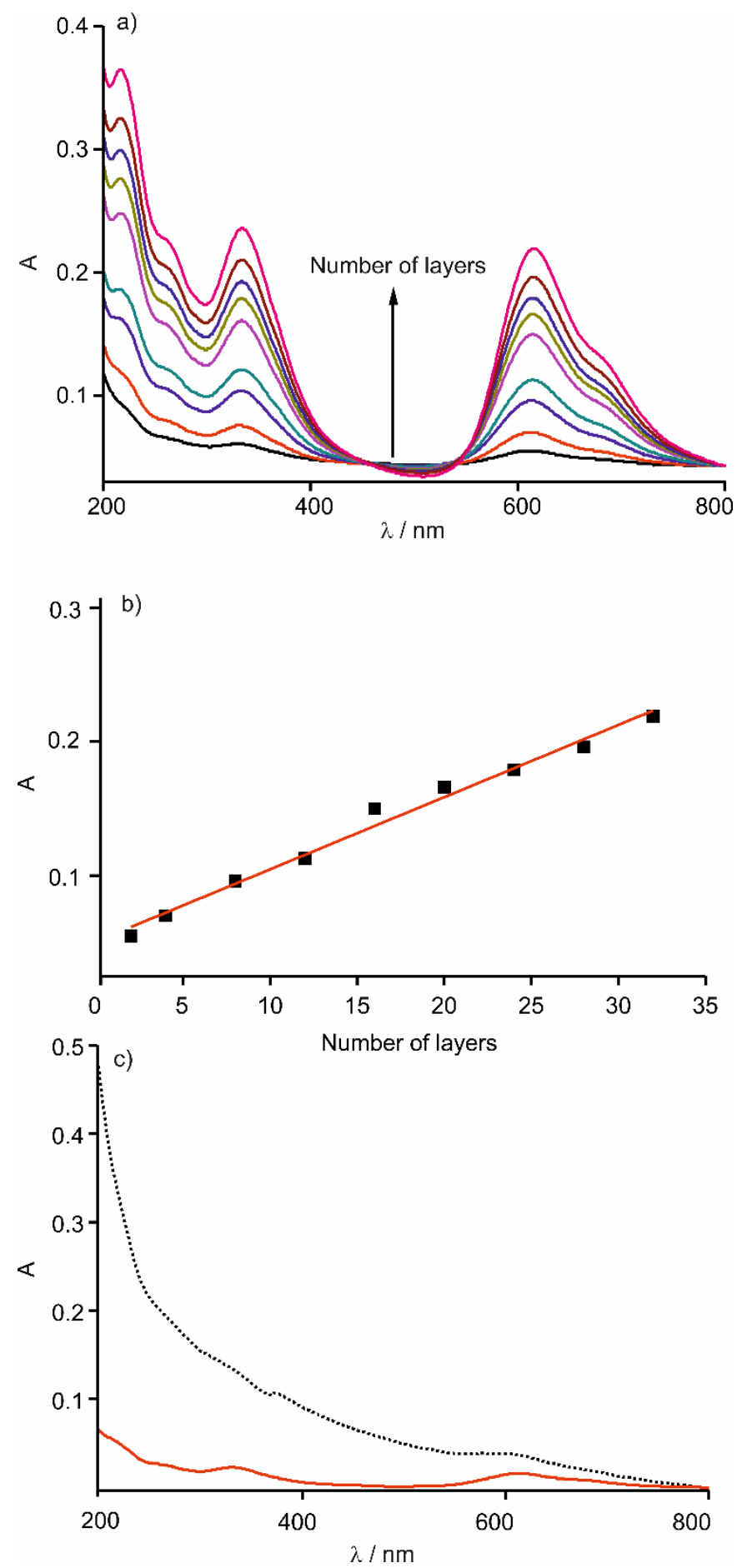

Figure 1. UV-Vis spectra of a) $\left[\mathrm{CHI}^{(+)}\left|\mathrm{CuPc}^{\mathrm{S}(-)}\right| \mathrm{IL}^{(+)} \mid \mathrm{CuPc}^{\mathrm{S}(-)}\right]_{n}$ LbL films with increasing number of layers $(\mathrm{n}=2,4,8,12,16,20,24,28,32)$; b) Correlation between the absorbance measured at $680 \mathrm{~nm}$ and the number of layers; c) comparison of the spectra of $\left[\mathrm{CHI}^{(+)}\left|\mathrm{CuPc}^{\mathrm{S}(-)}\right| \mathrm{IL}^{(+)} \mid \mathrm{CuPc}^{\mathrm{S}(-)}\right]_{2}$ (solid line) and of $\left[\mathrm{CHI}^{(+)}\left|\mathrm{CuPc}^{\mathrm{S}(-)}\right| \mathrm{IL}^{(+)} \mid \mathrm{CuPc}^{\mathrm{S}(-)}\right]_{2} \mid$ Lac (dotted line). 

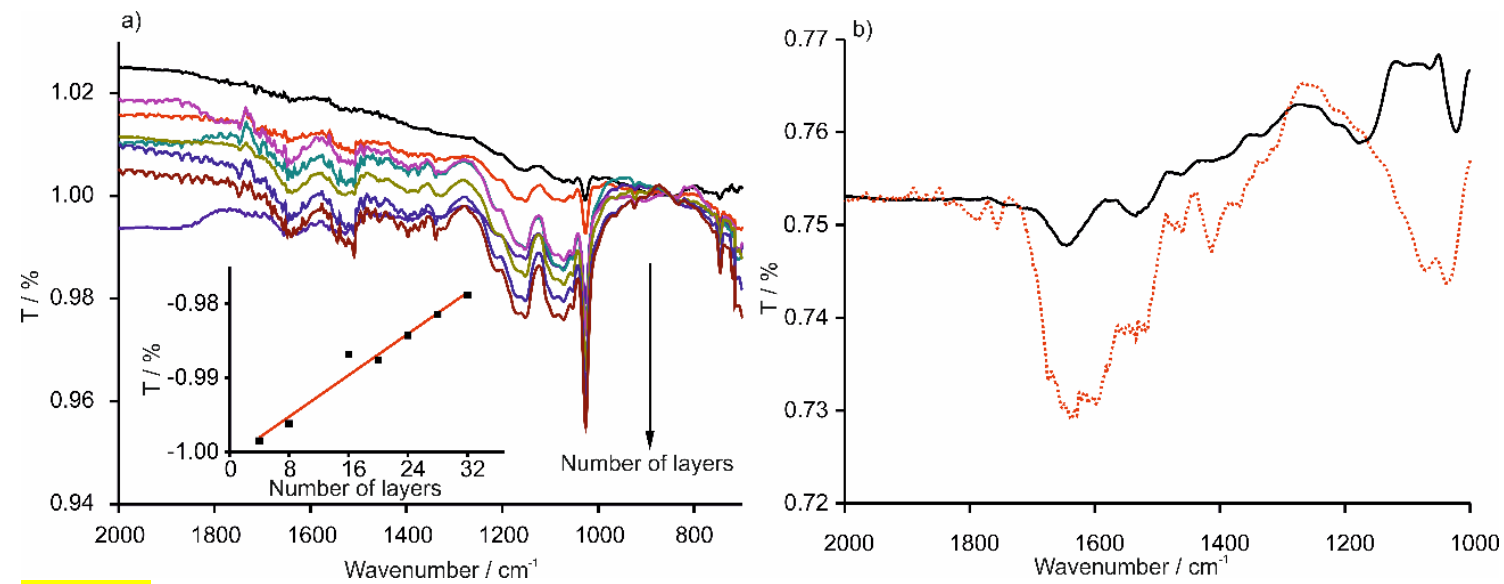

Figure 2. a) FTIR spectra of LbL $\left[\mathrm{CHI}^{(+)}+\mathrm{IL}^{(+)} \mid \mathrm{CuPc}^{\mathrm{S}(-)}\right]_{\mathrm{n}}$ films with increasing number of layers $(\mathrm{n}=$ $4,8,12,16,20,24,28,32)$. The inset shows the correlation between the transmittance measured at $1027 \mathrm{~cm}^{-1}$ and the number of layers. b) Comparison of the spectra of $\left[\mathrm{CHI}^{(+)}+\mathrm{IL}^{(+)} \mid \mathrm{CuPc}^{\mathrm{S}(-)}\right]_{16}$ (solid line) and of $\left[\mathrm{CHI}^{(+)}+\mathrm{IL}^{(+)} \mid \mathrm{CuPc}^{\mathrm{S}(-)}\right]_{16} \mid \mathrm{Lac}$ (dotted line). 

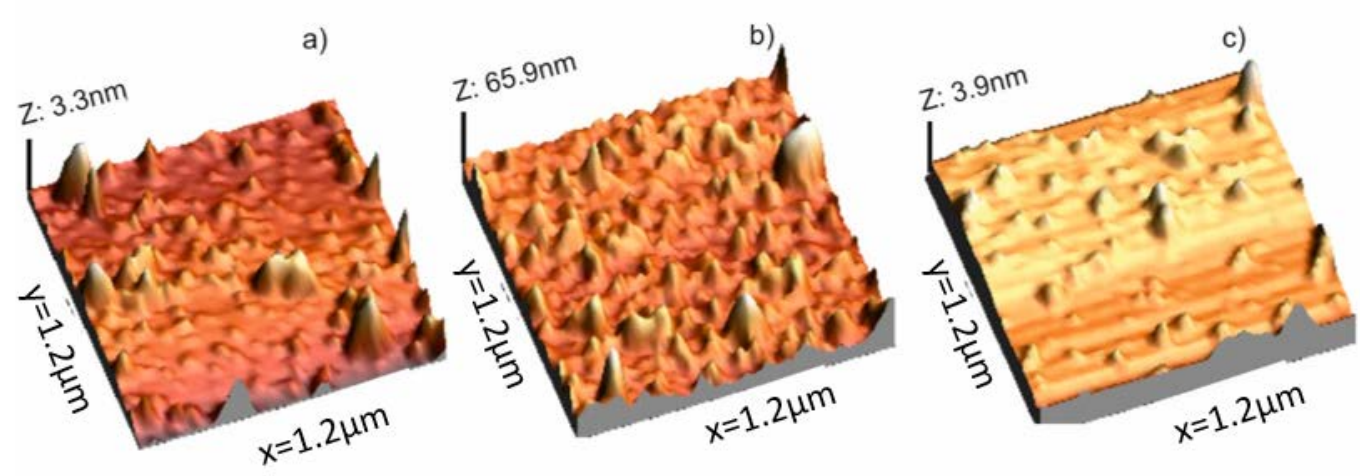

d)
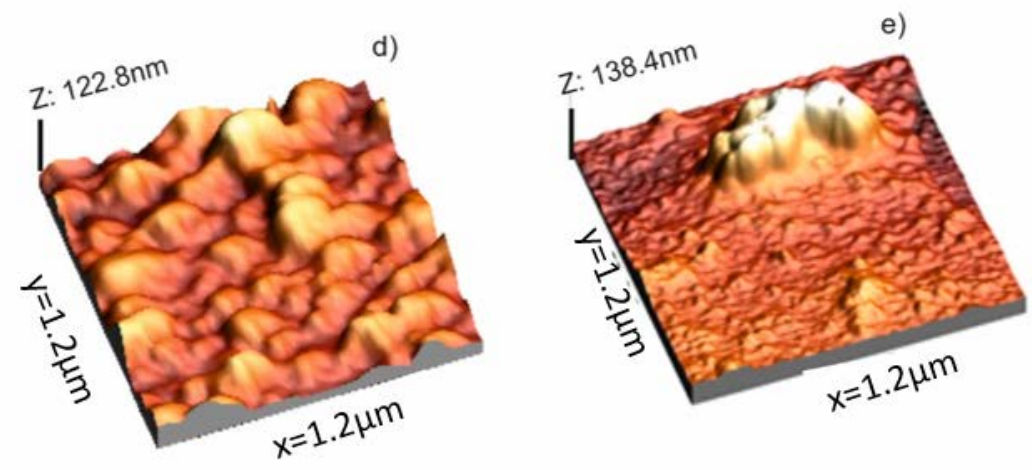

Figure 3. $\mathrm{AFM}$ topographic images of a) $\left[\mathrm{CHI}^{(+)}+\mathrm{IL}^{(+)} \mid \mathrm{CuPc}^{\mathrm{S}(-)}\right]_{2} ;$ b) $\left[\mathrm{CHI}^{(+)}+\mathrm{IL}^{(+)} \mid \mathrm{CuPc}^{\mathrm{S}(-)}\right]_{12} ;$ c) $\left[\mathrm{CHI}^{(+)}\left|\mathrm{CuPc}^{\mathrm{S}(-)}\right| \mathrm{IL}^{(+)} \mid \mathrm{CuPc}^{\mathrm{S}(-)}\right]_{2} ; \quad$ d) $\quad\left[\mathrm{CHI}^{(+)}\left|\mathrm{CuPc}^{\mathrm{S}(-)}\right|\left[\mathrm{IL}^{(+)} \mid \mathrm{CuPc}^{\mathrm{S}(-)}\right]_{12}\right.$ and e) $\left[\mathrm{CHI}^{(+)}+\mathrm{IL}^{(+)} \mid \mathrm{CuPc}^{\mathrm{S}(-)}\right]_{2} \mid \mathrm{Lac}$ "Note that the vertical heights of surface features varied from $\approx 3 \mathrm{~nm}$ (panels a and c) to $>120 \mathrm{~nm}$ (panels d and e)" 


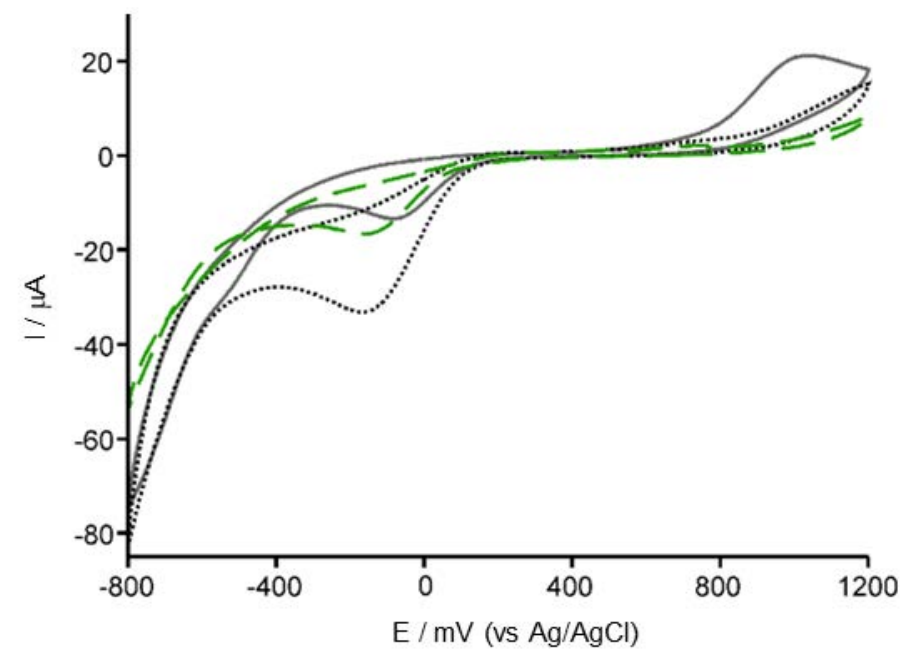

Figure 4. Cyclic voltammograms of $\left[\mathrm{CHI}^{(+)}+\mathrm{IL}^{(+)} \mid \mathrm{CuPc}^{\mathrm{S}(-)}\right]_{2}(\ldots),\left[\mathrm{CHI}^{(+)}+\mathrm{IL}^{(+)} \mid \mathrm{CuPc}^{\mathrm{S}(-)}\right]_{2} \mid \mathrm{Lac}($ .....), and $\left[\mathrm{CHI}^{(+)}+\mathrm{IL}^{(+)} \mid \mathrm{CuPc}^{\mathrm{S}(-)}\right]_{2}\left|\mathrm{CHI}^{(+)}+\mathrm{IL}^{(+)}\right| \mathrm{Lac}\left(\right.$ - - - ) immersed in $10^{-4} \mathrm{M}$ catechol in $0.01 \mathrm{M}$ phosphate buffer (pH 7.00). Scan rate $100 \mathrm{mV} \cdot \mathrm{s}^{-1}$. 

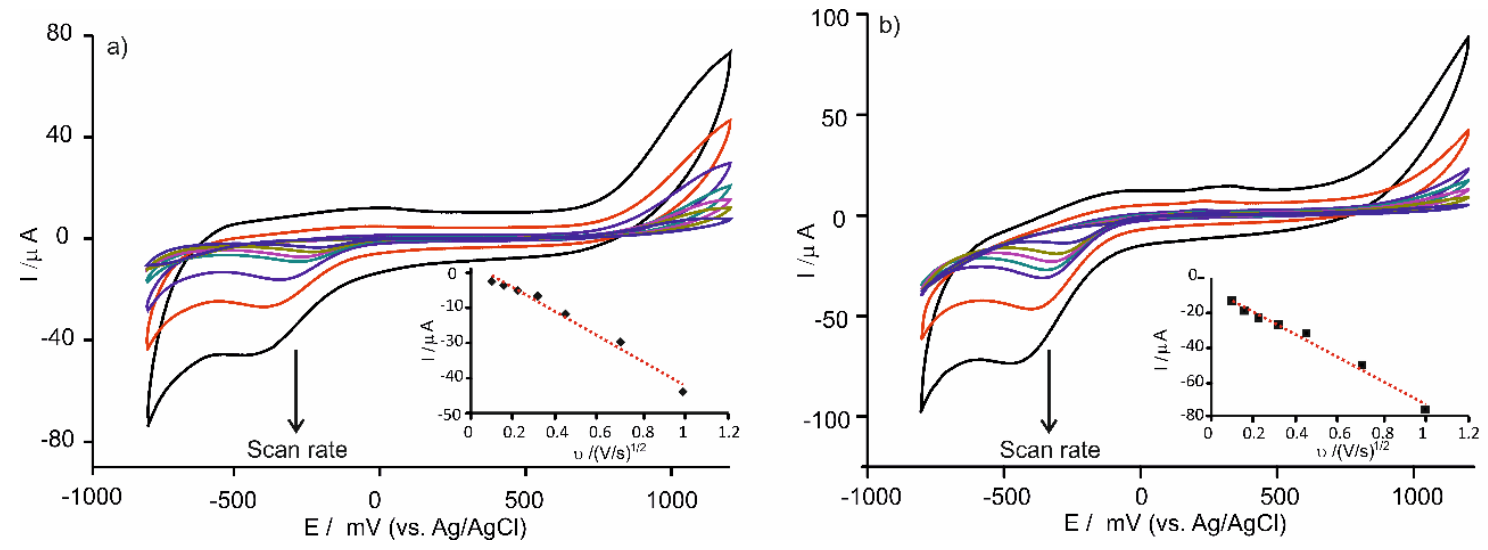

Figure 5. CV registered at increasing scan rates from 10 to $1000 \mathrm{mV} / \mathrm{s}$ immersed in $10^{-4} \mathrm{M}$ catechol in $0.01 \mathrm{M}$ phosphate buffer ( $\mathrm{pH}$ 7.00) for: a) the $\left[\mathrm{CHI}^{(+)}+\mathrm{IL}^{(+)} \mid \mathrm{CuPc}^{(-)}\right]_{2}$ sensor; and b) the $\left[\mathrm{CHI}^{(+)}+\mathrm{IL}^{(+)} \mid \mathrm{CuPc}^{\mathrm{S}(-)}\right]_{2} \mid \mathrm{Lac}$ biosensor. The insets show the linear relationship between $\mathrm{I}_{\mathrm{pc}}$ and the square root of the scan rate. 


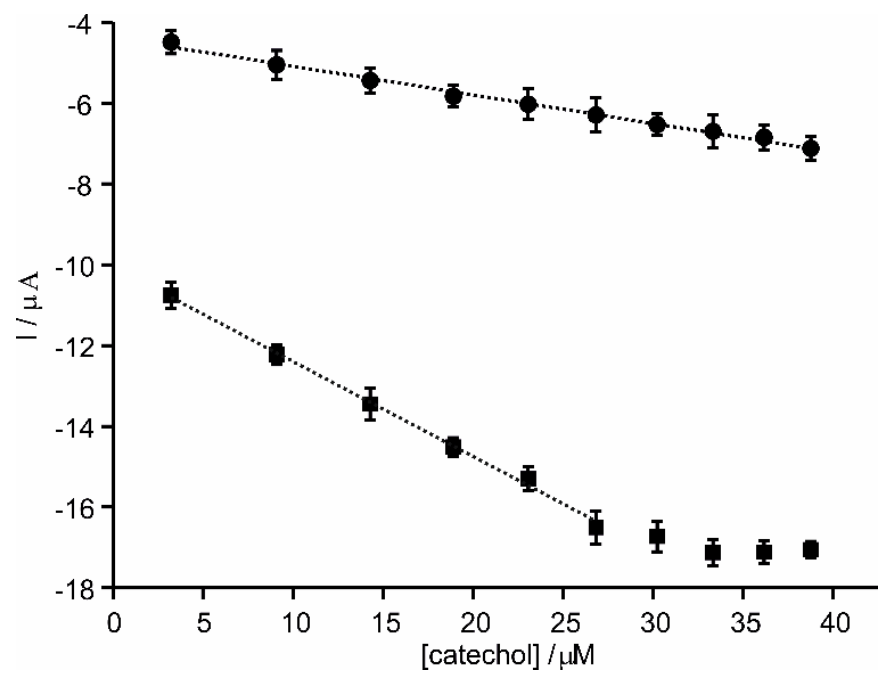

Figure 6. Relationship of the amperometric responses to catechol addition with the working electrode potential fixed at $-200 \mathrm{mV}$ immersed in $0.01 \mathrm{M}$ phosphate buffer $(\mathrm{pH} 7.00)$ for the $\left[\mathrm{CHI}^{(+)}+\mathrm{IL}^{(+)}\right.$ $\left.\mathrm{CuPcS}^{(-)}\right]_{2}$ sensor (upper) and the $\left[\mathrm{CHI}^{(+)}+\mathrm{IL}^{(+)} \mid \mathrm{CuPcS}^{(-)}\right]_{2} \mid \mathrm{Lac}$ biosensor (lower). Error bars correspond to the errors registered in three replicate experiments. 
Table 1. FTIR bands of the $\left[\mathrm{CHI}^{(+)}+\mathrm{IL}^{(+)} \mid \mathrm{CuPc}^{\mathrm{S}(-)}\right]_{2}$ sensor and of the individual components

\begin{tabular}{|c|c|c|c|c|}
\hline $\begin{array}{l}\text { Wavelength } \\
\left(\mathrm{cm}^{-1}\right)\end{array}$ & $\begin{array}{l}\mathrm{IL}^{(+)} \\
\left(\mathrm{cm}^{-1}\right)\end{array}$ & $\begin{array}{l}\mathrm{CHI}^{(+)} \\
\left(\mathrm{cm}^{-1}\right)\end{array}$ & $\begin{array}{l}\mathrm{CuPc}^{\mathrm{s}(-)} \\
\left(\mathrm{cm}^{-1}\right)\end{array}$ & Assignment \\
\hline 3424 & & $3478 s$ & & $\begin{array}{l}\text { OH stretching vibrations, } \\
\text { Intermolecular H Bonds }\end{array}$ \\
\hline 2926 & 2973 & 2924 & 2923 & $\begin{array}{l}(\mathrm{C}-\mathrm{H}) \text { asymmetric stretching } \\
\text { vibration in alkyl }\end{array}$ \\
\hline 2845 & 2888 & 2856 & 2854 & $\begin{array}{l}(\mathrm{C}-\mathrm{H}) \text { asymmetric stretching } \\
\text { vibration in alkyl }\end{array}$ \\
\hline 1657 & & 1656 & & $\mathrm{C}=\mathrm{O}$ stretching in amide group \\
\hline 1647 & 1652 & & & the $\mathrm{C}=\mathrm{C}$ and $\mathrm{C}=\mathrm{N}$ stretching \\
\hline 1610 & & & 1612 & $\begin{array}{l}\text { (C-C) stretching vibration in } \\
\text { pyrrole }\end{array}$ \\
\hline 1546 & 1572 & & & $\begin{array}{l}\text { C-C stretching of the imidazole } \\
\text { ring }\end{array}$ \\
\hline 1546 & & 1571 & & $\mathrm{~N}-\mathrm{H}$ bending \\
\hline 1510 & & & 1542 & $(\mathrm{C}-\mathrm{H})$ bending vibration \\
\hline 1461 & $1463 \mathrm{~s}$ & & & $\begin{array}{l}\mathrm{CH}_{3} \text { and } \mathrm{CH}_{2} \text { asymmetric bending } \\
\text { of alkyl substituent in imidazolium } \\
\text { ionic liquids }\end{array}$ \\
\hline 1456 & 1469 & & $1468 \mathrm{sh}$ & Isoindole stretching \\
\hline 1456 & $1458 \mathrm{sh}$ & & 1450 & $(\mathrm{C}-\mathrm{H})$ in plane bending \\
\hline 1419 & & 1422 & & $(\mathrm{CH}-\mathrm{OH})$ bending \\
\hline 1395 & & 1378 & & $\left(\mathrm{CH}_{2} \mathrm{OH}\right)$ \\
\hline 1338 & & & $1330 \mathrm{vs}$ & $(\mathrm{C}-\mathrm{C})$ in isoindole \\
\hline 1216 & & & 1410 & $\begin{array}{l}\mathrm{S}=\mathrm{O} \text { Symmetric stretching } \\
\text { vibration }\end{array}$ \\
\hline 1169s & 1167 & & & C-N stretching \\
\hline 1150 & & & 1145 & $\begin{array}{l}\mathrm{S}=\mathrm{O} \text { Symmetric stretching } \\
\text { vibration }\end{array}$ \\
\hline 1093 & & & $1114 v s$ & $\beta(\mathrm{C}-\mathrm{H})$ bending in plane \\
\hline 1072 & 1069 & & & $\mathrm{C}-\mathrm{H}$ deformation in plane \\
\hline 1051 & & & 1048 & S-O stretching \\
\hline 1027vs & & & 1060 & $\begin{array}{l}v(\mathrm{C}-\mathrm{N}) \text { stretching in pyrrole } \\
\text { vibration }\end{array}$ \\
\hline 832 & 847 & & & C-H bending \\
\hline 742 & 744 & & & $\mathrm{C}-\mathrm{H}$ plane bending \\
\hline 720 & & & $723 \mathrm{vs}$ & $\gamma(\mathrm{C}-\mathrm{H})$ out of plane deformation \\
\hline
\end{tabular}

vs: very strong, s: strong, sh: shoulder, w:weak 
Table 2. Comparison of analytical parameters of different biosensors dedicated to the detection of catechol.

\begin{tabular}{|c|c|c|c|c|c|c|c|}
\hline Biosensor description & $\begin{array}{c}\text { Potential } \\
\text { (V) }\end{array}$ & $\mathbf{R}^{2}$ & $\begin{array}{l}K^{a p p} \\
(\mu \mathrm{M})\end{array}$ & $\begin{array}{l}\text { Sensitivity } \\
\left(\mathbf{A} \mathbf{M}^{-1}\right)\end{array}$ & $\begin{array}{c}\text { LOD } \\
(\mathrm{M})\end{array}$ & $\begin{array}{c}\text { [Catechol] } \\
(\mu \mathrm{M})\end{array}$ & Ref. \\
\hline$\left[\mathrm{CHI}^{(+)}+\mathrm{IL}^{(+)} \mid \mathrm{CuPc}^{\mathrm{S}(-)}\right]_{2} \mid \mathrm{Lac}$ & -0.2 & 0.981 & 3.16 & 0.23 & $9.98 \cdot 10^{-9}$ & $2.4-14.9$ & This work \\
\hline Lac/PANI/GCE & --- & 0.989 & --- & 0.706 & $2.07 \cdot 10^{-6}$ & $3.2-19.6$ & {$[8]$} \\
\hline $\mathrm{Fe}_{3} \mathrm{O}_{4}$-PANI/Lac/CHI/CPE & -1.5 & 0.995 & 1.09 & 126.00 & $4.0 \cdot 10^{-7}$ & $0.5-80$ & {$[56]$} \\
\hline Lac/AP-rGOs/GCE & 0.37 & 0.998 & 3000 & 15.79 & $7.0 \cdot 10^{-6}$ & $15-700$ & {$[57]$} \\
\hline Lac/Si/MWCNTs/SPEs & -0.12 & 0.991 & 3.78 & 2780.00 & $4.2 \cdot 10^{-7}$ & $1.3-85.5$ & [58] \\
\hline Carbon-fiber/Lac & -0.1 & 0.999 & 610 & 0.33 & --- & $1-10$ & [59] \\
\hline $\begin{array}{c}\text { Au-SAM/AuNPs- } \\
\text { Linker/Fullerenols/Lac }\end{array}$ & -0.1 & 0.999 & 0.66 & --- & $6.0 \cdot 10^{-6}$ & $30-300$ & {$[60]$} \\
\hline Lac/AA/LuPc 2 & 0.06 & 0.992 & --- & 0.360 & $5.18 \cdot 10^{-7}$ & $4-150$ & [61] \\
\hline $\mathrm{TiO}_{2} / \mathrm{NAF} / \mathrm{Lac}$ & --- & 0.996 & --- & 2.94 & $1.25 \cdot 10^{-6}$ & $0.75-150$ & {$[62]$} \\
\hline MMCNTs/Lac/CHI & -0.05 & 0.999 & --- & 0.279 & $3.34 \cdot 10^{-8}$ & $0.1-165$ & [63] \\
\hline
\end{tabular}


Table 3. Comparison of the results obtained with the sensor and the corresponding biosensor

\begin{tabular}{cccccc}
\hline Sensor description & $\begin{array}{c}\text { Intensity } \\
\text { Current } \\
(\boldsymbol{\mu} \mathbf{A})\end{array}$ & $\mathbf{R}^{2}$ & $\begin{array}{c}\boldsymbol{K}_{M p}^{a p p} \\
(\boldsymbol{\mu M})\end{array}$ & $\begin{array}{c}\text { Sensitivity } \\
\left(\mathbf{A ~ M}^{-1}\right)\end{array}$ & $\begin{array}{c}\mathbf{L O D}^{-10} \\
(\mathbf{M})\end{array}$ \\
\hline$\left[\mathbf{C H I}^{(+)}+\mathbf{I L}^{(+)} \mid \mathbf{C u P c}^{\mathbf{S}(-)}\right]_{2}$ & -12 & 0.993 & --- & $0.070 \pm 0.001$ & $2.17 \pm 0.17$ \\
\hline$\left[\mathbf{C H I}^{(+)}+\mathbf{I L}^{(+)} \mid \mathbf{C u P c}^{\mathbf{S}(-)}\right]_{2} \mid \mathbf{L a c}$ & -33 & 0.997 & 3.16 & $0.237 \pm 0.001$ & $0.08 \pm 0.001$ \\
\hline
\end{tabular}



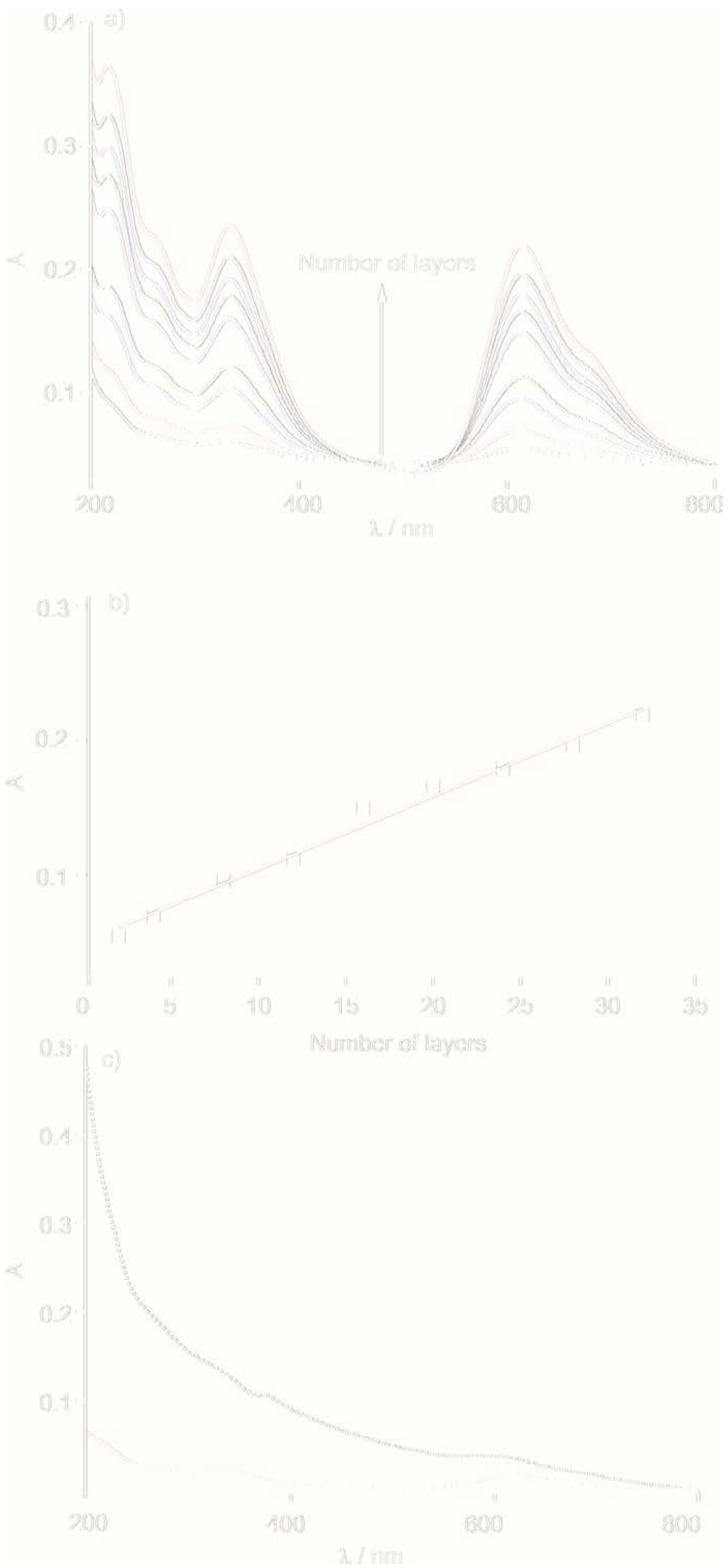

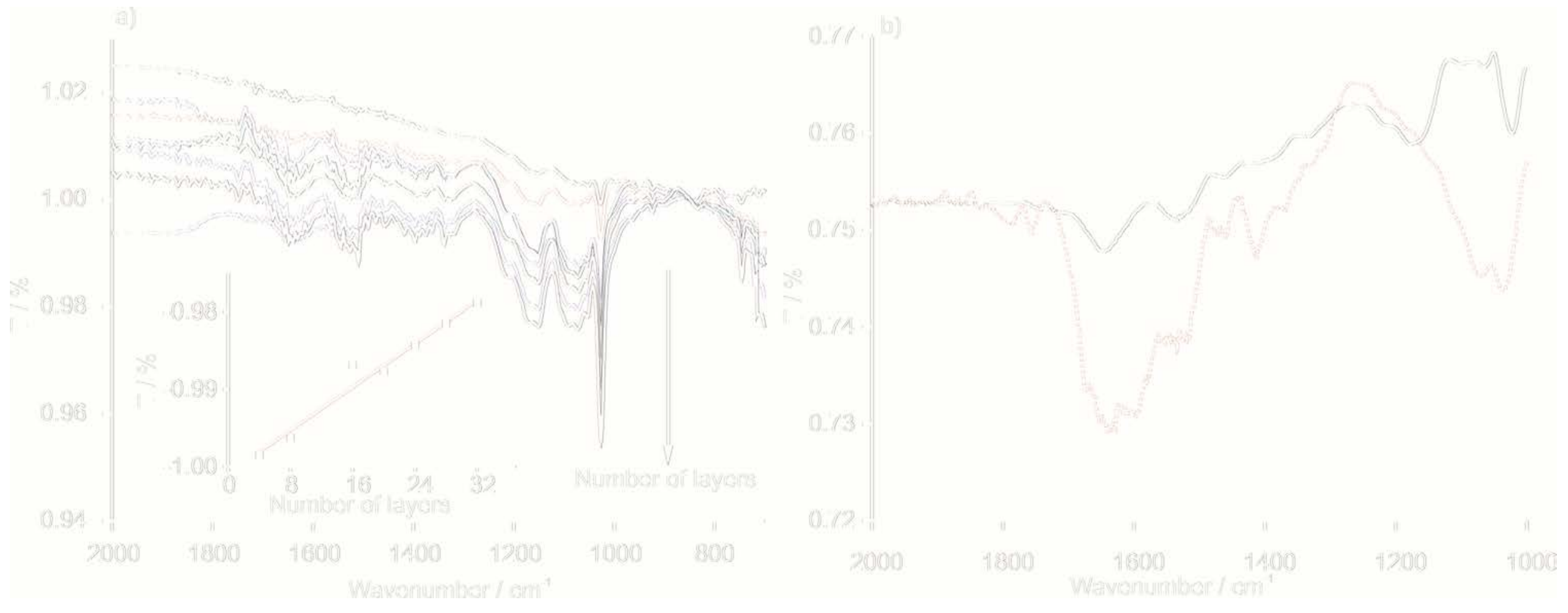
a)
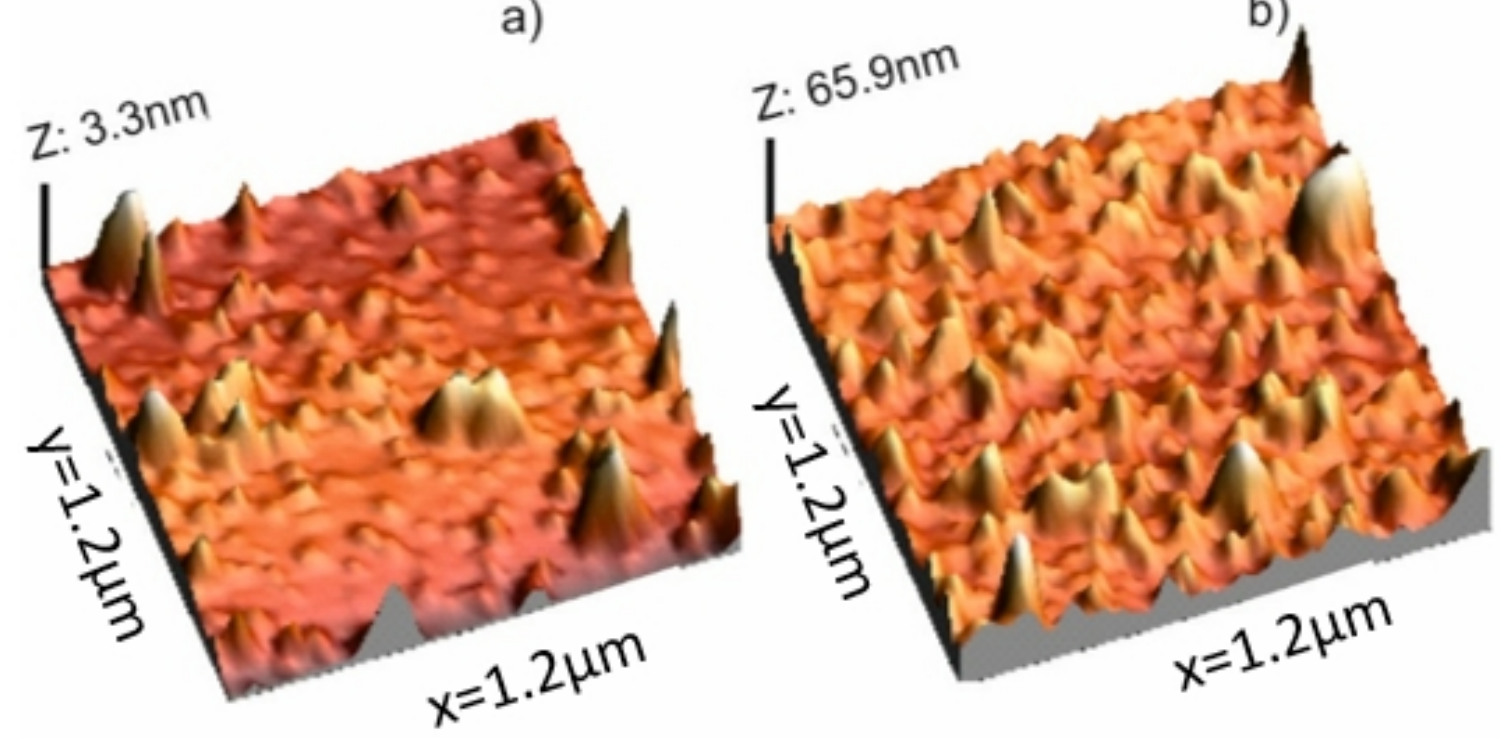

d)

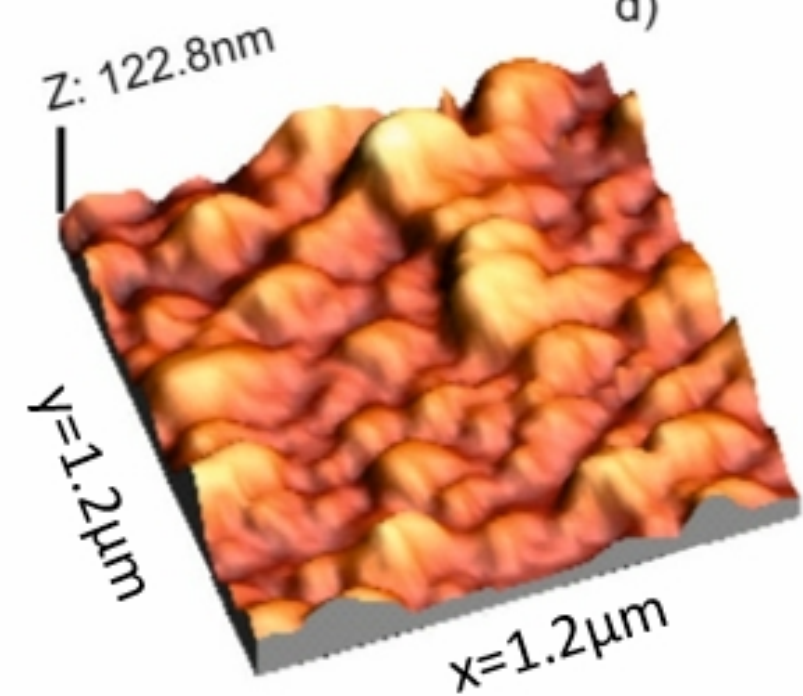

c)

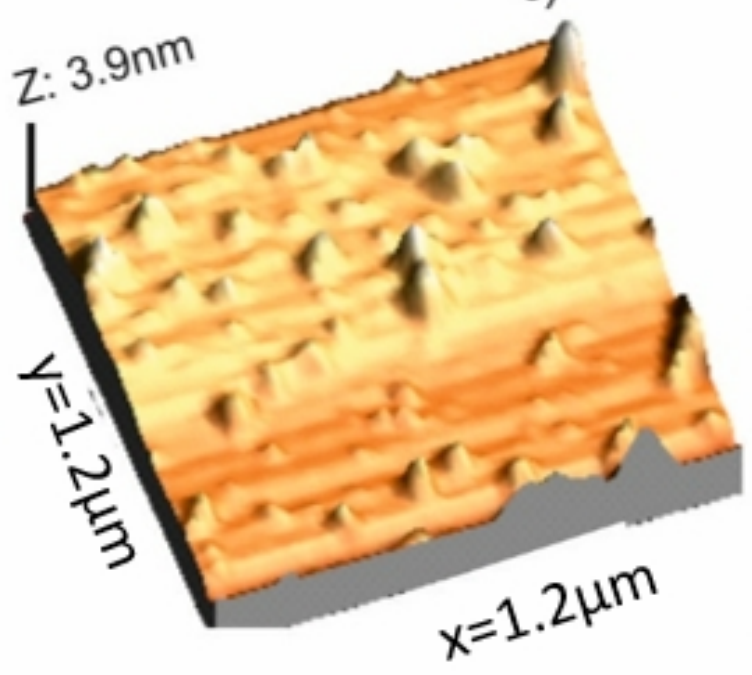

e) $z: 138.4 n m$

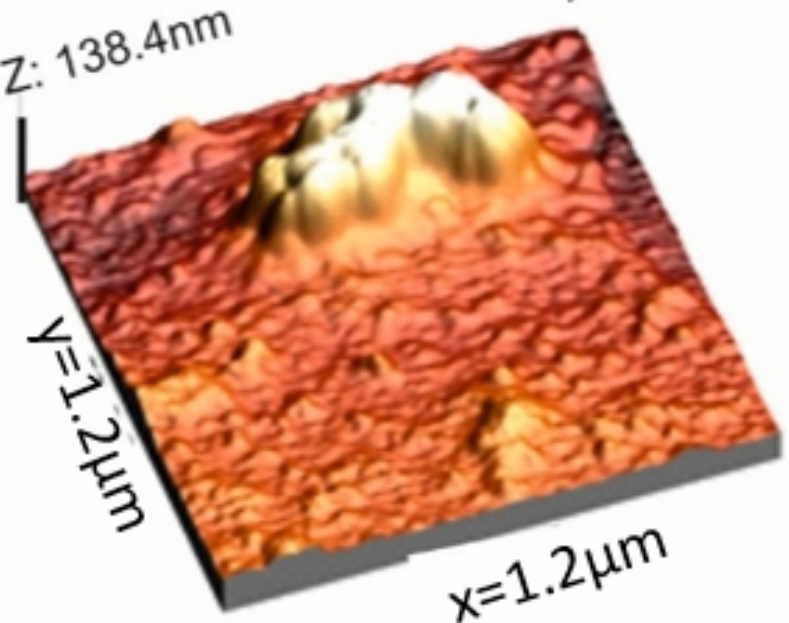




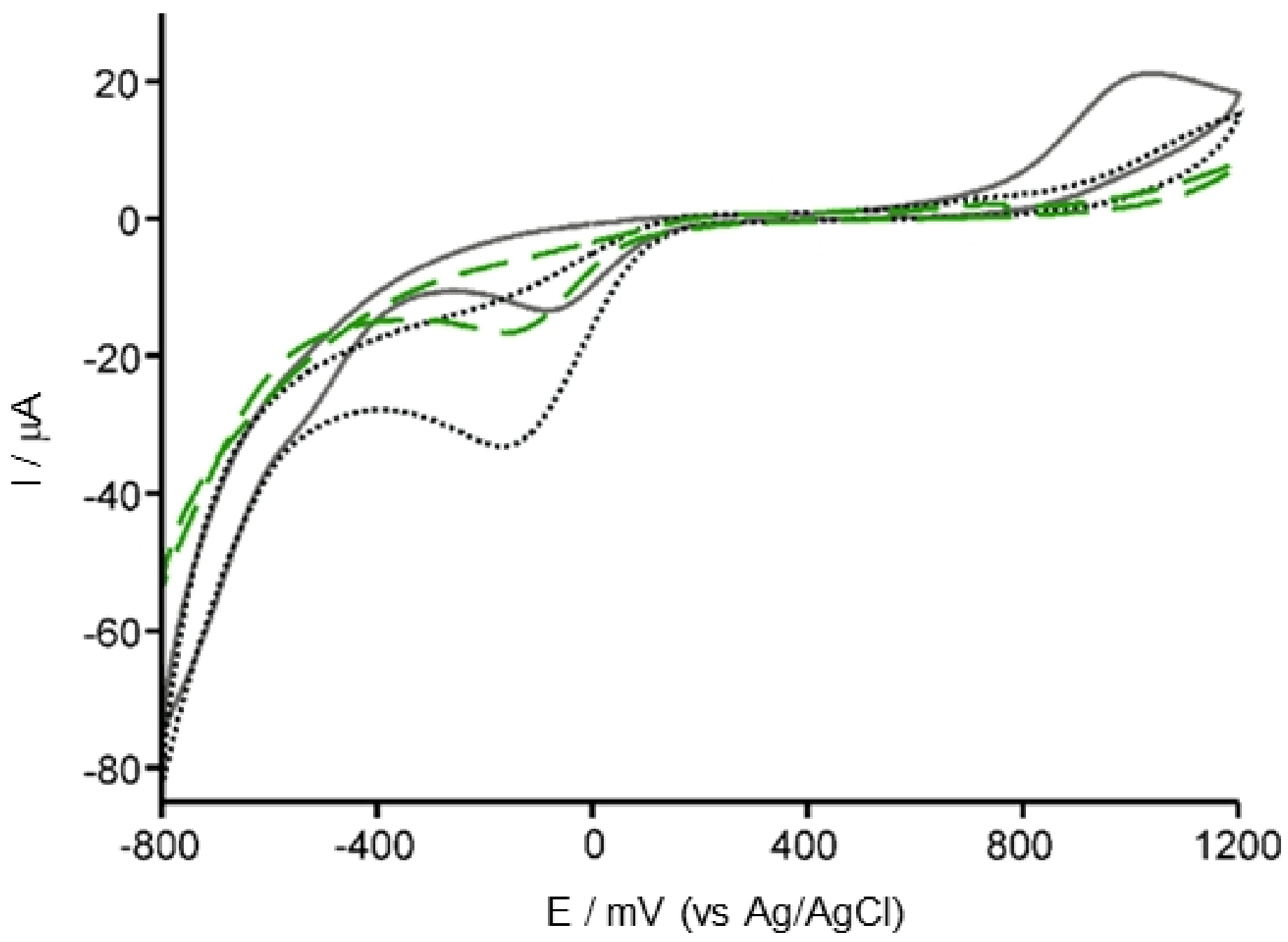



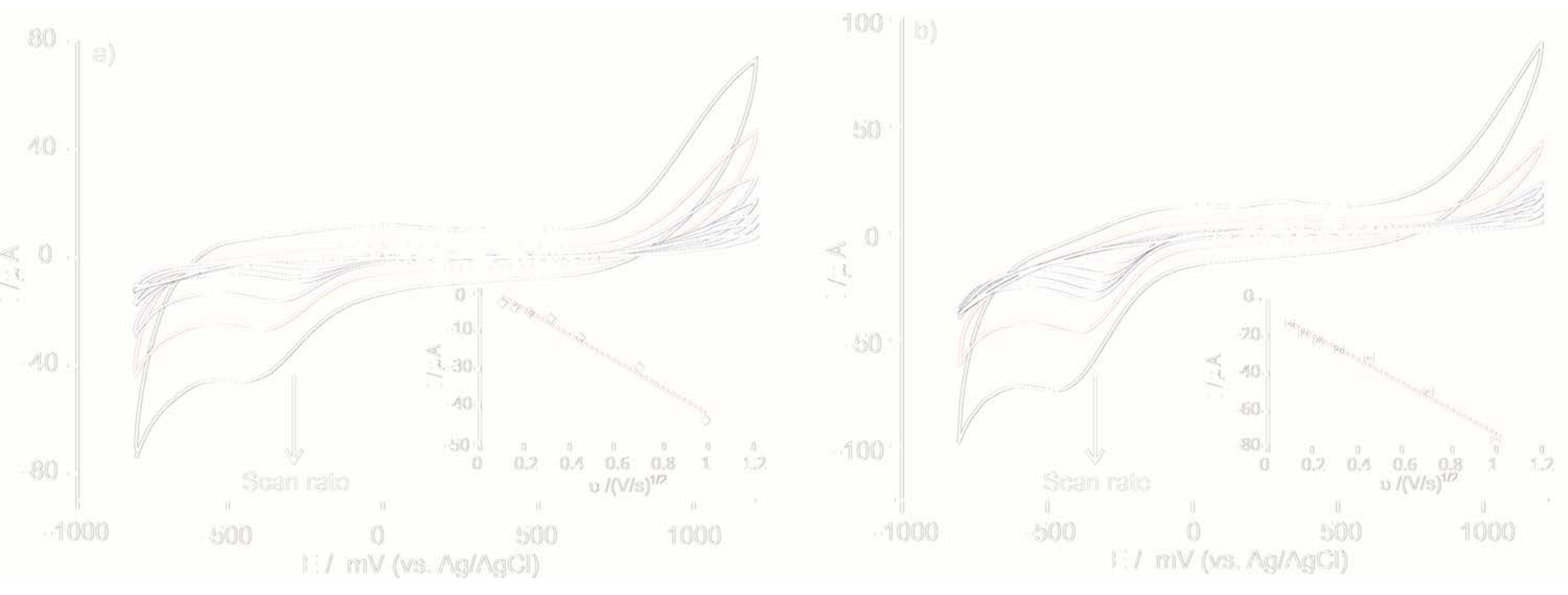


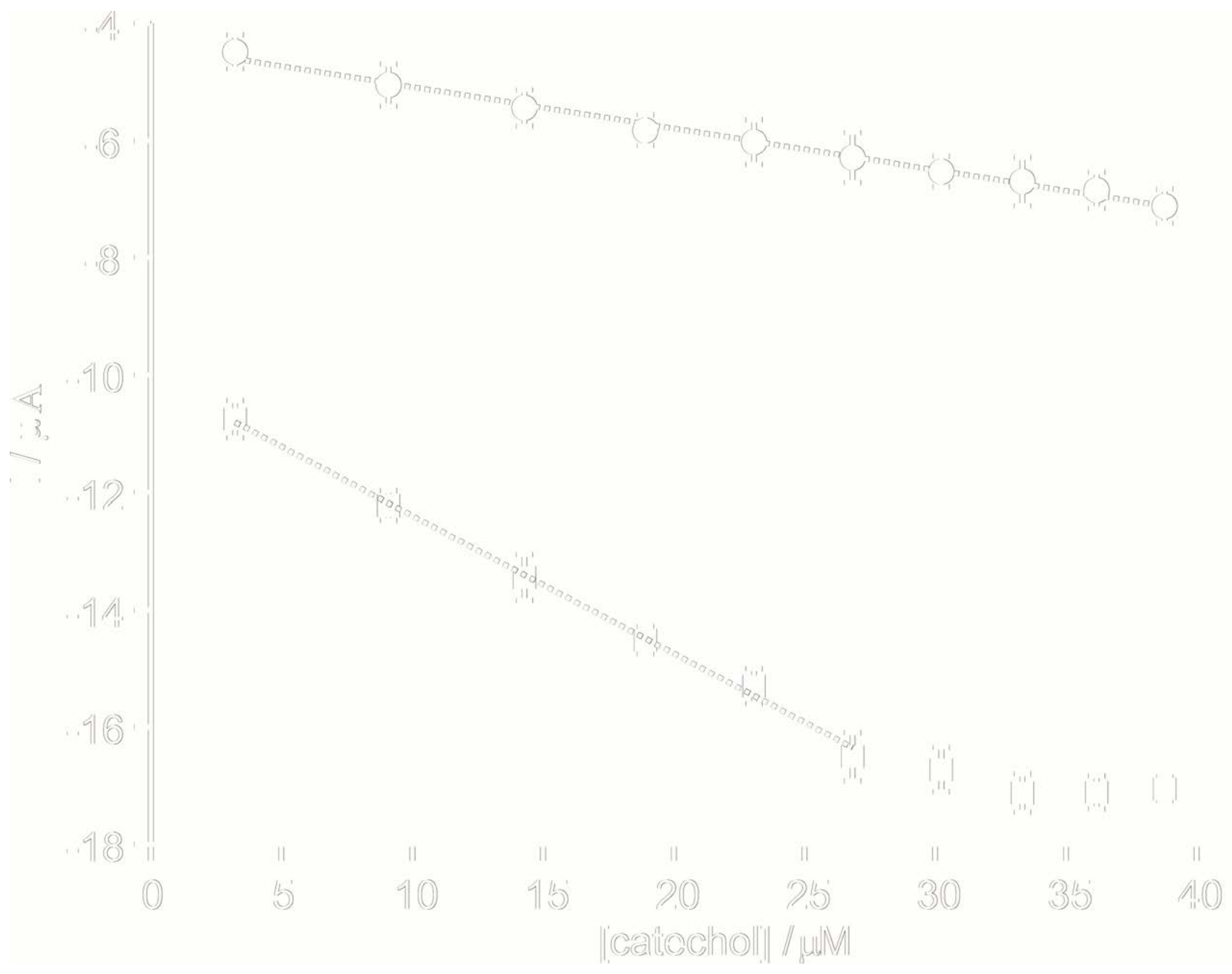


Table 1. FTIR bands of $\left[\mathrm{CHI}^{(+)}+\mathrm{IL}^{(+)} \mid \mathrm{CuPc}^{\mathrm{S}(-)}\right]_{2}$ sensor and of the individual components

\begin{tabular}{|c|c|c|c|c|}
\hline $\begin{array}{l}\text { Wavelength } \\
\left(\mathrm{cm}^{-1}\right)\end{array}$ & $\begin{array}{l}\mathrm{IL}^{(+)} \\
\left(\mathrm{cm}^{-1}\right)\end{array}$ & $\begin{array}{l}\mathrm{CHI}^{(+)} \\
\left(\mathrm{cm}^{-1}\right)\end{array}$ & $\begin{array}{l}\mathrm{CuPc}^{\mathrm{s}(-)} \\
\left(\mathrm{cm}^{-1}\right)\end{array}$ & Assignment \\
\hline 3424 & & $3478 \mathrm{~s}$ & & $\begin{array}{l}\text { OH stretching vibrations, } \\
\text { Intermolecular H Bonds }\end{array}$ \\
\hline 2926 & 2973 & 2924 & 2923 & $\begin{array}{l}(\mathrm{C}-\mathrm{H}) \text { asymmetric stretching } \\
\text { vibration in alkyl }\end{array}$ \\
\hline 2845 & 2888 & 2856 & 2854 & $\begin{array}{l}(\mathrm{C}-\mathrm{H}) \text { asymmetric stretching } \\
\text { vibration in alkyl }\end{array}$ \\
\hline 1657 & & 1656 & & $\mathrm{C}=\mathrm{O}$ stretching in amide group \\
\hline 1647 & 1652 & & & the $\mathrm{C}=\mathrm{C}$ and $\mathrm{C}=\mathrm{N}$ stretching \\
\hline 1610 & & & 1612 & $\begin{array}{l}\text { (C-C) stretching vibration in } \\
\text { pyrrole }\end{array}$ \\
\hline 1546 & 1572 & & & $\begin{array}{l}\mathrm{C}-\mathrm{C} \text { stretching of the imidazole } \\
\text { ring }\end{array}$ \\
\hline 1546 & & 1571 & & $\mathrm{~N}-\mathrm{H}$ bending \\
\hline 1510 & & & 1542 & $(\mathrm{C}-\mathrm{H})$ bending vibration \\
\hline 1461 & $1463 \mathrm{~s}$ & & & $\begin{array}{l}\mathrm{CH}_{3} \text { and } \mathrm{CH}_{2} \text { asymmetric bending } \\
\text { of alkyl substituent in imidazolium } \\
\text { ionic liquids }\end{array}$ \\
\hline 1456 & 1469 & & $1468 \mathrm{sh}$ & Isoindole stretching \\
\hline 1456 & $1458 \mathrm{sh}$ & & 1450 & $(\mathrm{C}-\mathrm{H})$ in plane bending \\
\hline 1419 & & 1422 & & $(\mathrm{CH}-\mathrm{OH})$ bending \\
\hline 1395 & & 1378 & & $\left(\mathrm{CH}_{2} \mathrm{OH}\right)$ \\
\hline 1338 & & & $1330 \mathrm{vs}$ & $(\mathrm{C}-\mathrm{C})$ in isoindole \\
\hline 1216 & & & 1410 & $\begin{array}{l}\mathrm{S}=\mathrm{O} \text { Symmetric stretching } \\
\text { vibration }\end{array}$ \\
\hline $1169 \mathrm{~s}$ & 1167 & & & C-N stretching \\
\hline 1150 & & & 1145 & $\begin{array}{l}\mathrm{S}=\mathrm{O} \text { Symmetric stretching } \\
\text { vibration }\end{array}$ \\
\hline 1093 & & & $1114 \mathrm{vs}$ & $\beta(\mathrm{C}-\mathrm{H})$ bending in plane \\
\hline 1072 & 1069 & & & $\mathrm{C}-\mathrm{H}$ deformation in plane \\
\hline 1051 & & & 1048 & S-O stretching \\
\hline $1027 v s$ & & & 1060 & $\begin{array}{l}v(\mathrm{C}-\mathrm{N}) \text { stretching in pyrrole } \\
\text { vibration }\end{array}$ \\
\hline 832 & 847 & & & $\mathrm{C}-\mathrm{H}$ bending \\
\hline 742 & 744 & & & $\mathrm{C}-\mathrm{H}$ plane bending \\
\hline 720 & & & $723 \mathrm{vs}$ & $\gamma(\mathrm{C}-\mathrm{H})$ out of plane deformation \\
\hline
\end{tabular}

vs: very strong, s: strong, sh: shoulder, w:weak 
Table 2. Comparison of analytical parameters of different biosensors dedicated to the detection of catechol.

\begin{tabular}{|c|c|c|c|c|c|c|c|}
\hline Biosensor description & $\begin{array}{c}\text { Potential } \\
\text { (V) }\end{array}$ & $\mathbf{R}^{2}$ & $\begin{array}{l}K^{a p p} \\
(\mu \mathbf{M})\end{array}$ & $\begin{array}{l}\text { Sensitivity } \\
\left(\mathbf{A ~} \mathbf{M}^{-1}\right)\end{array}$ & $\begin{array}{c}\text { LOD } \\
(\mathbf{M})\end{array}$ & $\begin{array}{c}\text { [Catechol] } \\
\quad(\mu \mathrm{M})\end{array}$ & Ref. \\
\hline$\left[\mathrm{CHI}^{(+)}+\mathrm{IL}^{(+)} \mid \mathrm{CuPc}^{\mathrm{S}(-)}\right]_{2} \mid \mathrm{Lac}$ & -0.2 & 0.981 & 3.16 & 0.23 & $9.98 \cdot 10^{-9}$ & $2.4-14.9$ & This work \\
\hline Lac/PANI/GCE & --- & 0.989 & --- & 0.706 & $2.07 \cdot 10^{-6}$ & $3.2-19.6$ & {$[8]$} \\
\hline $\mathrm{Fe}_{3} \mathrm{O}_{4}$-PANI/Lac/CHI/CPE & -1.5 & 0.995 & 1.09 & 126.00 & $4.0 \cdot 10^{-7}$ & $0.5-80$ & {$[56]$} \\
\hline Lac/AP-rGOs/GCE & 0.37 & 0.998 & 3000 & 15.79 & $7.0 \cdot 10^{-6}$ & $15-700$ & [57] \\
\hline Lac/Si/MWCNTs/SPEs & -0.12 & 0.991 & 3.78 & 2780.00 & $4.2 \cdot 10^{-7}$ & $1.3-85.5$ & {$[58]$} \\
\hline Carbon-fiber/Lac & -0.1 & 0.999 & 610 & 0.33 & --- & $1-10$ & [59] \\
\hline $\begin{array}{c}\text { Au-SAM/AuNPs- } \\
\text { Linker/Fullerenols/Lac }\end{array}$ & -0.1 & 0.999 & 0.66 & --- & $6.0 \cdot 10^{-6}$ & $30-300$ & [60] \\
\hline $\mathrm{Lac} / \mathrm{AA} / \mathrm{LuPc}_{2}$ & 0.06 & 0.992 & --- & 0.360 & $5.18 \cdot 10^{-7}$ & $4-150$ & {$[61]$} \\
\hline $\mathrm{TiO}_{2} / \mathrm{NAF} / \mathrm{Lac}$ & --- & 0.996 & --- & 2.94 & $1.25 \cdot 10^{-6}$ & $0.75-150$ & {$[62]$} \\
\hline MMCNTs/Lac/CHI & -0.05 & 0.999 & --- & 0.279 & $3.34 \cdot 10^{-8}$ & $0.1-165$ & {$[63]$} \\
\hline
\end{tabular}


Table 3. Comparison of the results obtained with the sensor and the corresponding biosensor

\begin{tabular}{cccccc}
\hline Sensor description & $\begin{array}{c}\text { Intensity } \\
\text { Current } \\
(\boldsymbol{\mu} \mathbf{A})\end{array}$ & $\mathbf{R}^{2}$ & $\begin{array}{c}\boldsymbol{K}_{M p}^{a p p} \\
(\boldsymbol{\mu M})\end{array}$ & $\begin{array}{c}\text { Sensitivity } \\
\left(\mathbf{A ~ M}^{-1}\right)\end{array}$ & $\begin{array}{c}\mathbf{L O D}^{-10} \\
(\mathbf{M})\end{array}$ \\
\hline$\left[\mathbf{C H I}^{(+)}+\mathbf{I L}^{(+)} \mid \mathbf{C u P c}^{\mathbf{S}(-)}\right]_{2}$ & -12 & 0.993 & --- & $0.070 \pm 0.001$ & $2.17 \pm 0.17$ \\
\hline$\left[\mathbf{C H I}{ }^{(+)}+\mathbf{I L}^{(+)} \mid \mathbf{C u P c}^{\mathrm{S}(-)}\right]_{2} \mid \mathbf{L a c}$ & -33 & 0.997 & 3.16 & $0.237 \pm 0.001$ & $0.08 \pm 0.001$ \\
\hline
\end{tabular}


Supplementary material for:

\section{PROMOTING THE LACCASE SENSING ACTIVITY FOR}

CATECHOL DETECTION USING LBL ASSEMBLIES OF

\section{CHITOSAN/IONIC LIQUID/ PHTHALOCYANINE AS}

\section{IMMOBILIZATION SURFACES}

C. Salvo-Comino ${ }^{\mathrm{a}, \mathrm{c}}$, C. Garcia-Hernandez ${ }^{\mathrm{a}, \mathrm{c}}$, C. Garcia-Cabezon ${ }^{\mathrm{b}, \mathrm{c}}$, M.L. Rodriguez-

$$
\text { Mendez } \mathrm{a}^{\mathrm{ac}, \text {,* }}
$$

${ }^{a}$ Group UVASens. Engineers School, Universidad de Valladolid, 47011 Valladolid (Spain).

${ }^{b}$ Group UVASens. Materials Science Department, Universidad de Valladolid, 47011 Valladolid (Spain).

${ }^{c}$ BioecoUVA Research Institute, Engineers School, Universidad de Valladolid, 47011 Valladolid (Spain).

E-mails: coral.salvo@alumnos.uva.es, celia.garcia.hernandez@uva.es, crigar@eii.uva.es,mluz@eii.uva.es

*Corresponding Author: Prof. María Luz Rodríguez-Méndez, Group UVASens, Escuela de Ingenierías Industriales, Paseo del Cauce, 59, 47011 Valladolid. Spain. Phone: +34 983 423540; FAX: +34 983 423310; e-mail: mluz@eii.uva.es 

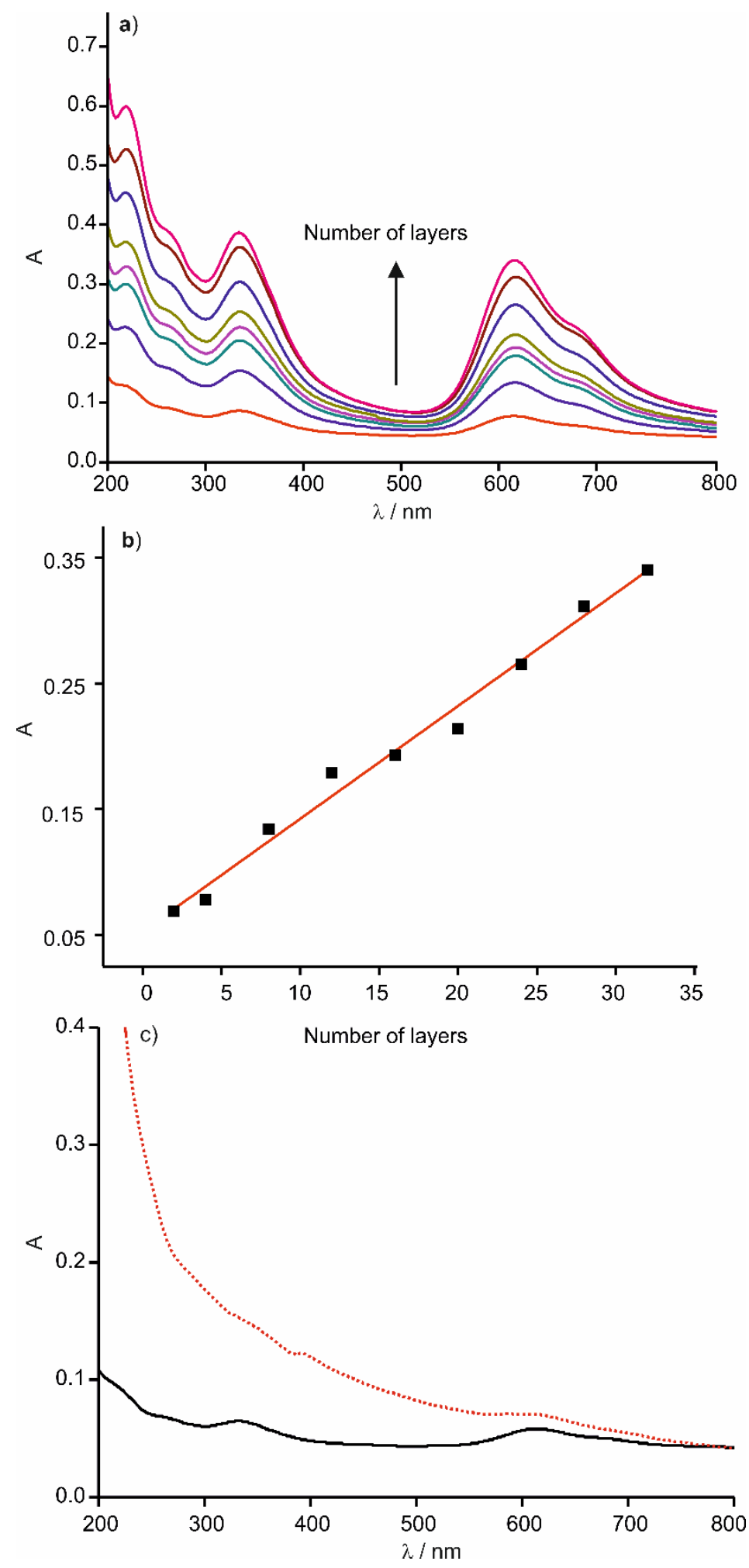

Figure S.1. UV-Vis spectra of a) $\left[\mathrm{CHI}^{(+)}+\mathrm{IL}^{(+)} \mid \mathrm{CuPc}^{\mathrm{S}(-)}\right]_{\mathrm{n}} \mathrm{LbL}$ films with increasing number of layers $(\mathrm{n}=$ $2,4,8,12,16,20,24,28,32)$. b) Correlation between the absorbance measured at $680 \mathrm{~nm}$ and the number of layers; c) comparison of the spectra of $\left[\mathrm{CHI}^{(+)}+\mathrm{IL}^{(+)} \mid \mathrm{CuPc}^{\mathrm{S}(-)}\right]_{2}$ (solid line) and of $\left[\mathrm{CHI}^{(+)}+\mathrm{IL}^{(+)} \mid \mathrm{CuPc}^{\mathrm{S}(-}\right.$ ]$_{2} \mid$ Lac (dotted line). 


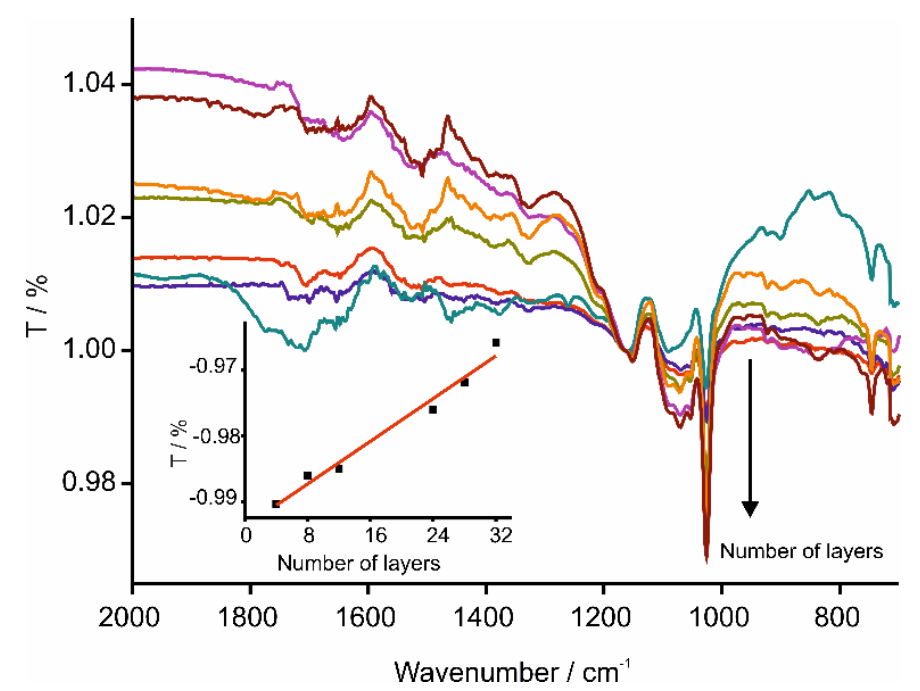

Figure S.2. FTIR spectra of $\mathrm{LbL}\left[\mathrm{CHI}^{(+)}\left|\mathrm{CuPc}^{\mathrm{S}(-)}\right| \mathrm{IL}^{(+)} \mid \mathrm{CuPc}^{\mathrm{S}(-)}\right]_{\mathrm{n}}$ films with increasing number of layers (n $=4,8,12,16,20,24,28,32)$. The inset shows the correlation between the transmittance measured at 1027 $\mathrm{cm}^{-1}$ and the number of layers. 


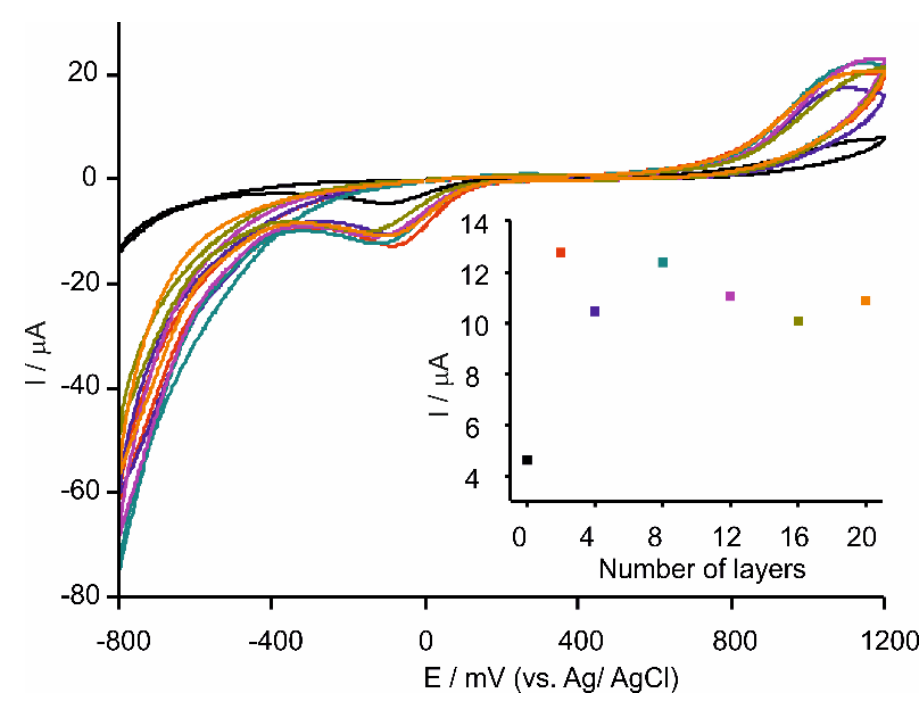

Figure S.3. Cyclic voltammograms of a $\left[\mathrm{CHI}^{(+)}+\mathrm{IL}^{(+)} \mid \mathrm{CuPc}^{\mathrm{S}(-)}\right]_{\mathrm{n}}$ with increasing number of layers $(\mathrm{n}=$ $0,24,8,12,16,20)$ immersed in $10^{-4} \mathrm{M}$ catechol in $0.01 \mathrm{M}$ phosphate buffer $(\mathrm{pH} 7.00)$. Scan rate $100 \mathrm{mV} \cdot \mathrm{s}^{-1}$. The inset shows the correlation between the intensity current at $-100 \mathrm{mV}$ and the number of layers. 


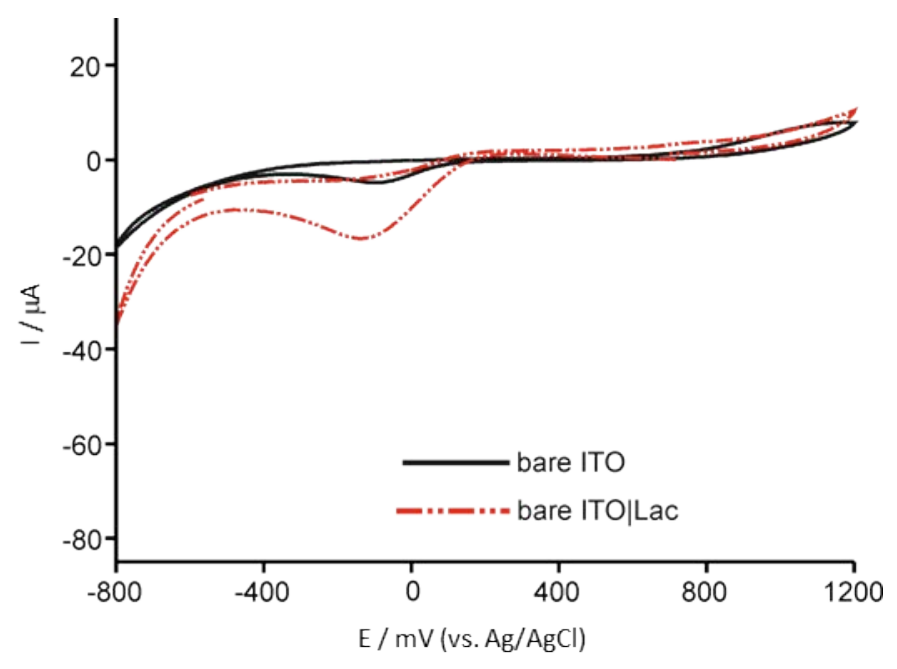

Figure S4. Cyclic voltammograms of a bare ITO and ITO|Lac immersed in $10^{-4} \mathrm{M}$ catechol in $0.01 \mathrm{M}$ phosphate buffer (pH 7.00). Scan rate $100 \mathrm{mV} . \mathrm{s}^{-1}$. 


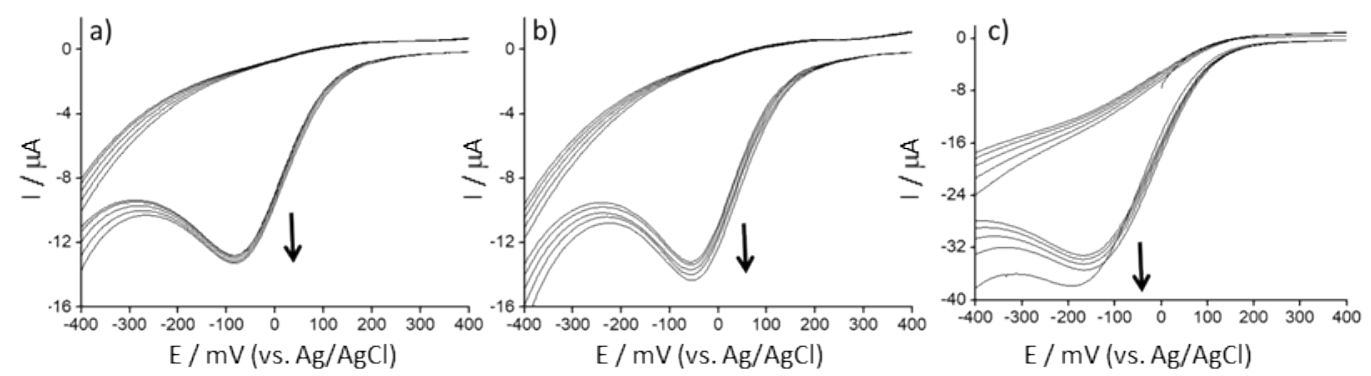

Figure S.5. Cyclic voltammograms of a) $\left[\mathrm{CHI}^{(+)}+\mathrm{IL}^{(+)} \mid \mathrm{CuPc}^{\mathrm{S}(-)}\right]_{2}$, b) $\left[\mathrm{CHI}^{(+)}\left|\mathrm{CuPc}^{\mathrm{S}(-)}\right| \mathrm{IL}^{(+)} \mid \mathrm{CuPc}^{\mathrm{S}(-)}\right]_{2}$ and c) $\left[\mathrm{CHI}^{(+)}+\mathrm{IL}^{(+)} \mid \mathrm{CuPc}^{\mathrm{S}(-)}\right]_{2} \mid \mathrm{Lac}$ immersed in $10^{-4} \mathrm{M}$ catechol in $0.01 \mathrm{M}$ phosphate buffer ( $\left.\mathrm{pH} 7.00\right)$. Scan rate $100 \mathrm{mV} \cdot \mathrm{s}^{-1}$. Cycles 1,3,5,7 and 10 are shown. 

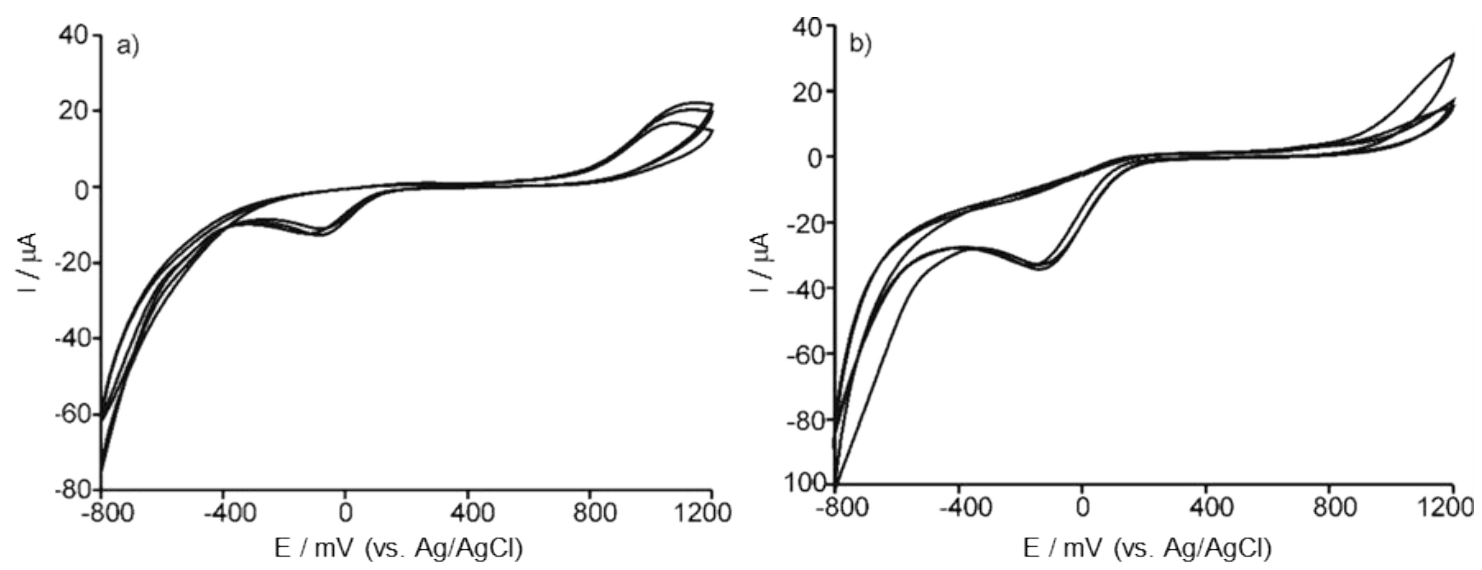

Figure S.6. Cyclic voltammograms of 3 different sensors prepared under the same condition of a) $\left[\mathrm{CHI}^{(+)}+\mathrm{IL}^{(+)} \mid \mathrm{CuPc}^{\mathrm{S}(-)}\right]_{2}$, and b) $\left[\mathrm{CHI}^{(+)}+\mathrm{IL}^{(+)} \mid \mathrm{CuPc}^{\mathrm{S}(-)}\right]_{2} \mid$ Lac immersed in $10^{-4} \mathrm{M}$ catechol in $0.01 \mathrm{M}$ phosphate buffer (pH 7.00). Scan rate $100 \mathrm{mV} . \mathrm{s}^{-1}$. 


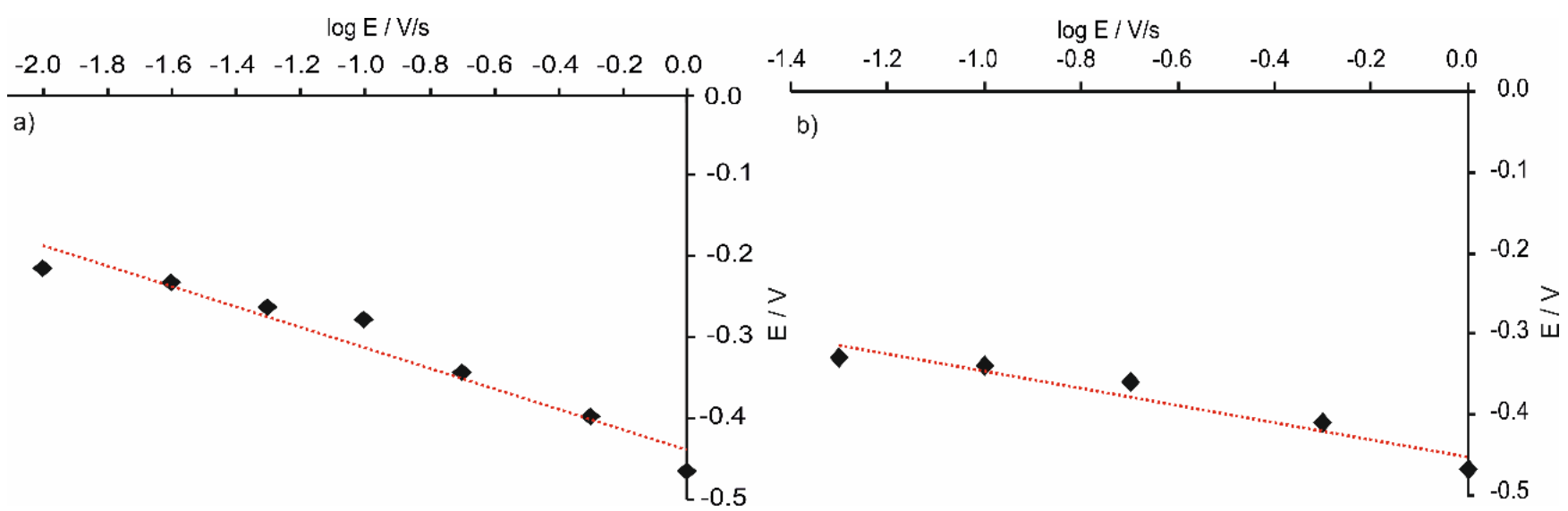

Figure S.7. Linear relationship between $\mathrm{E}_{\mathrm{pc}}$ vs. $\log \mathrm{V}$ shown by the a) $\left[\mathrm{CHI}^{(+)}+\mathrm{IL}^{(+)} \mid \mathrm{CuPc}^{\mathrm{S}(-)}\right]_{2}$ sensor and b) $\left[\mathrm{CHI}^{(+)}+\mathrm{IL}^{(+)} \mid \mathrm{CuPc}^{\mathrm{S}(-)}\right]_{2} \mid \mathrm{Lac}$ biosensor immersed in $10^{-4} \mathrm{M}$ catechol in $0.01 \mathrm{M}$ phosphate buffer $(\mathrm{pH}$ 7.00). 

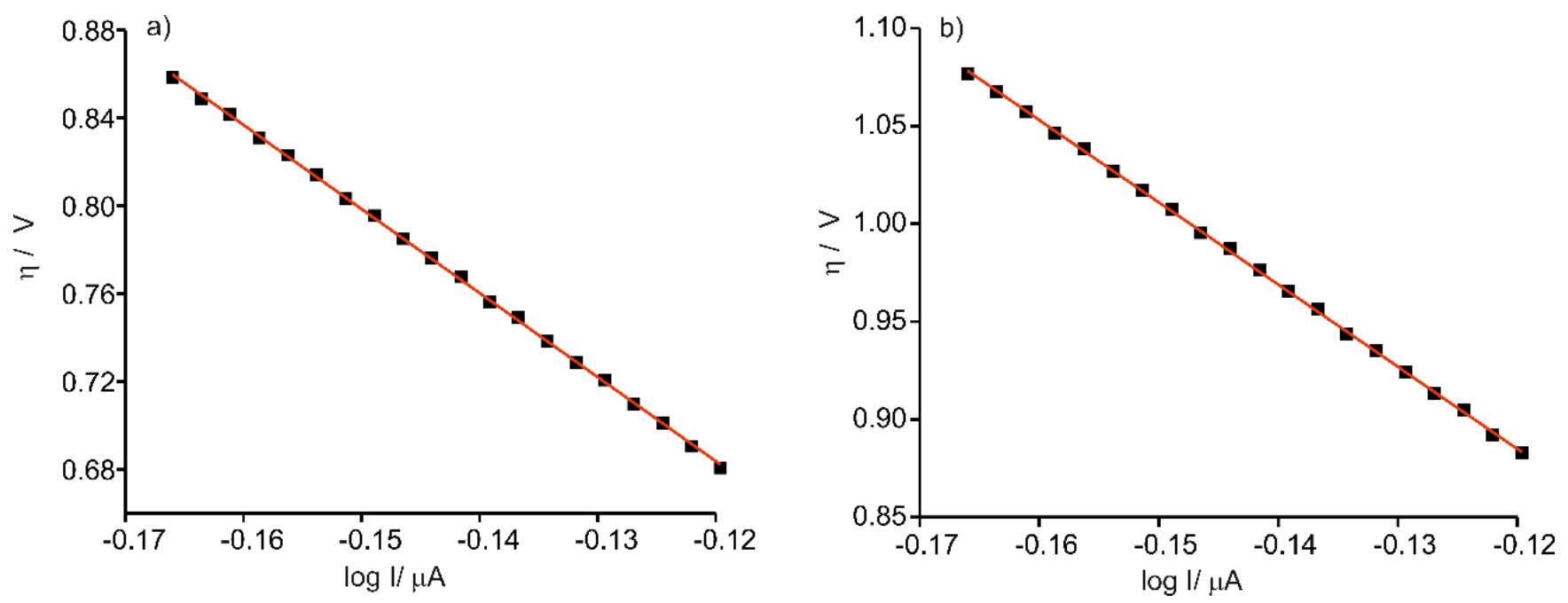

Figure S.8. Linear relationship between $\log \mathrm{I}_{\mathrm{pc}}$ vs. $\eta$ shown by the a) $\left[\mathrm{CHI}^{(+)}+\mathrm{IL}^{(+)} \mid \mathrm{CuPc}^{\mathrm{S}(-)}\right]_{2}$ sensor and b) $\left[\mathrm{CHI}^{(+)}+\mathrm{IL}^{(+)} \mid \mathrm{CuPc}^{\mathrm{S}(-)}\right]_{2} \mid \mathrm{Lac}$ biosensor immersed in $10^{-4} \mathrm{M}$ catechol in $0.01 \mathrm{M}$ phosphate buffer $(\mathrm{pH}$ 7.00). 

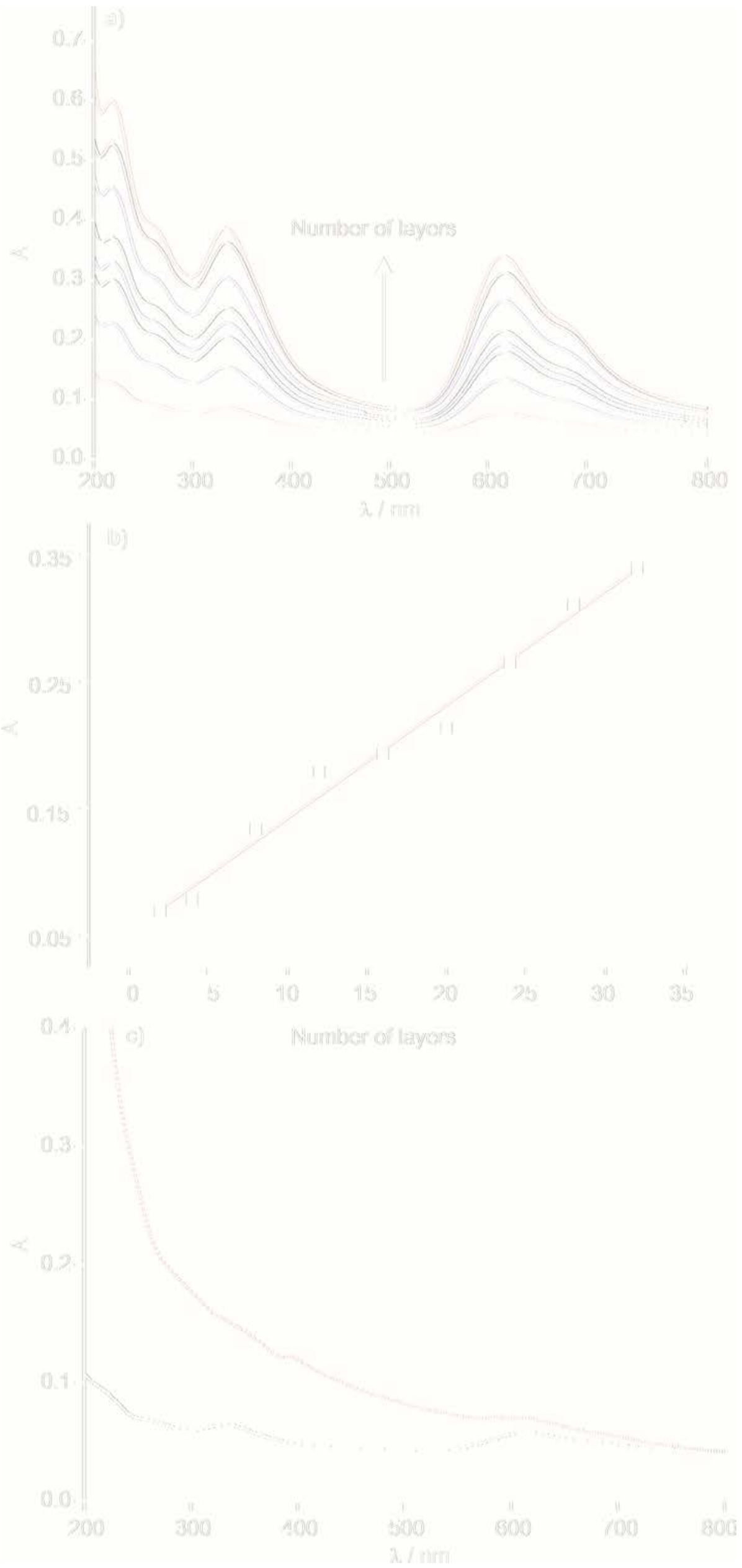


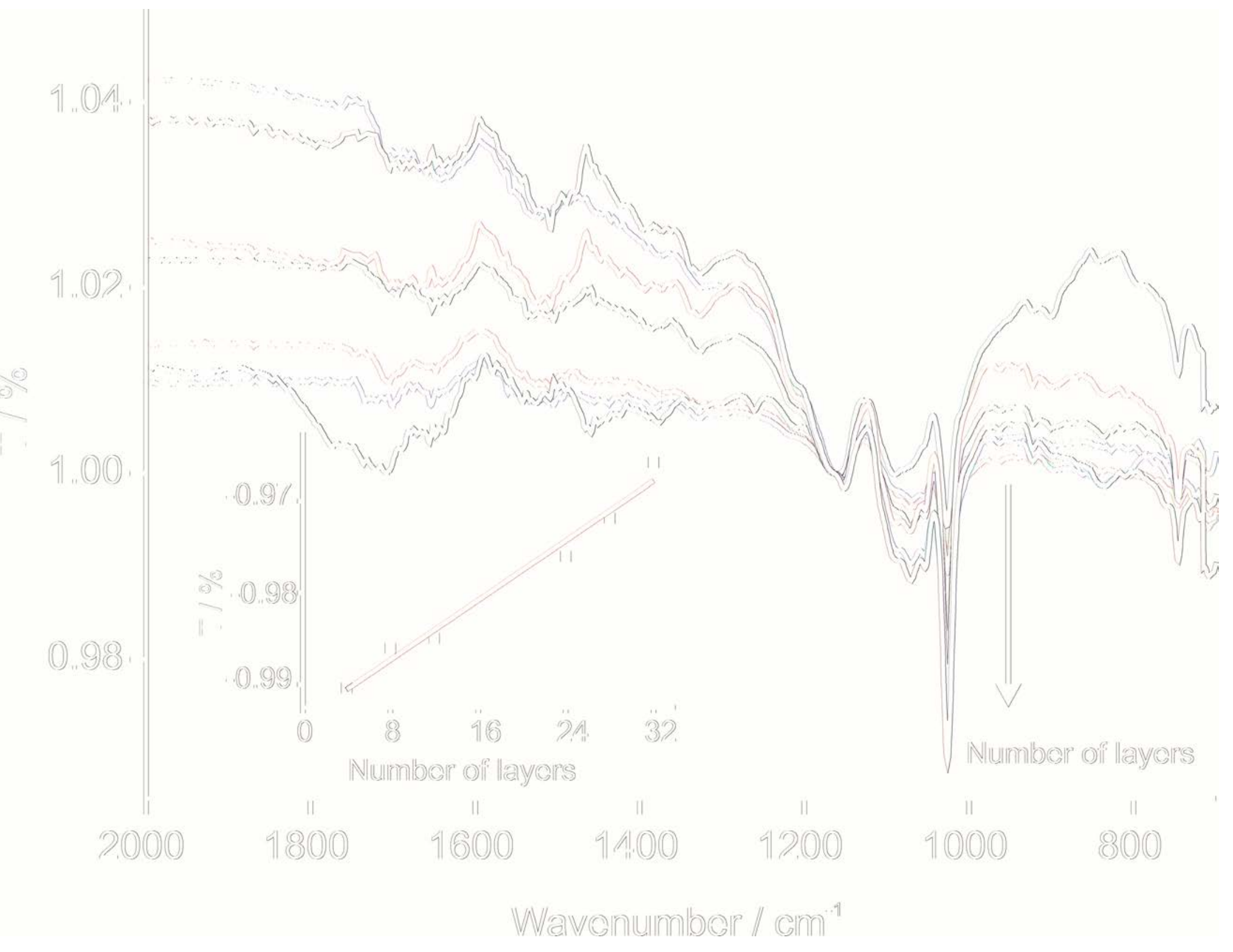




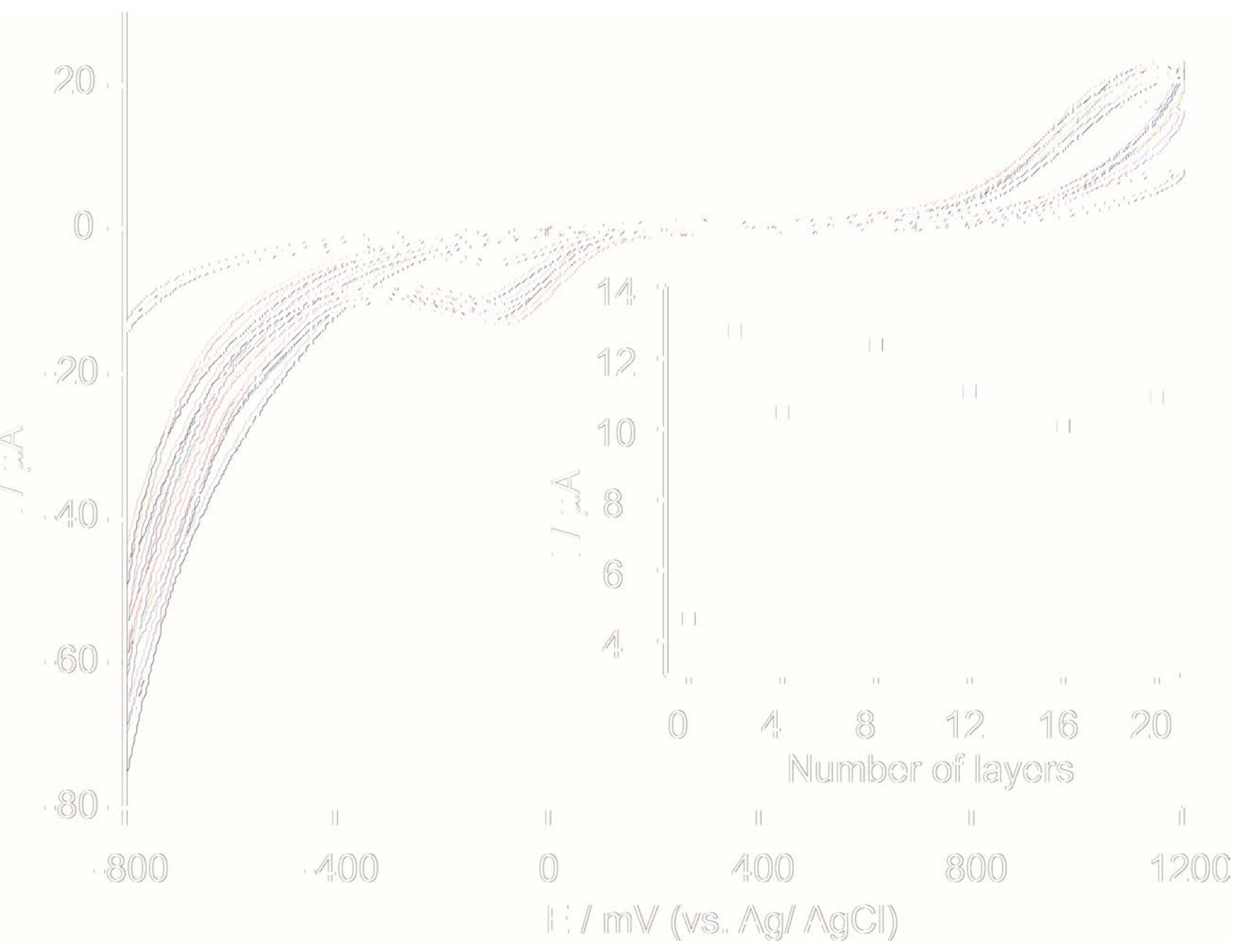




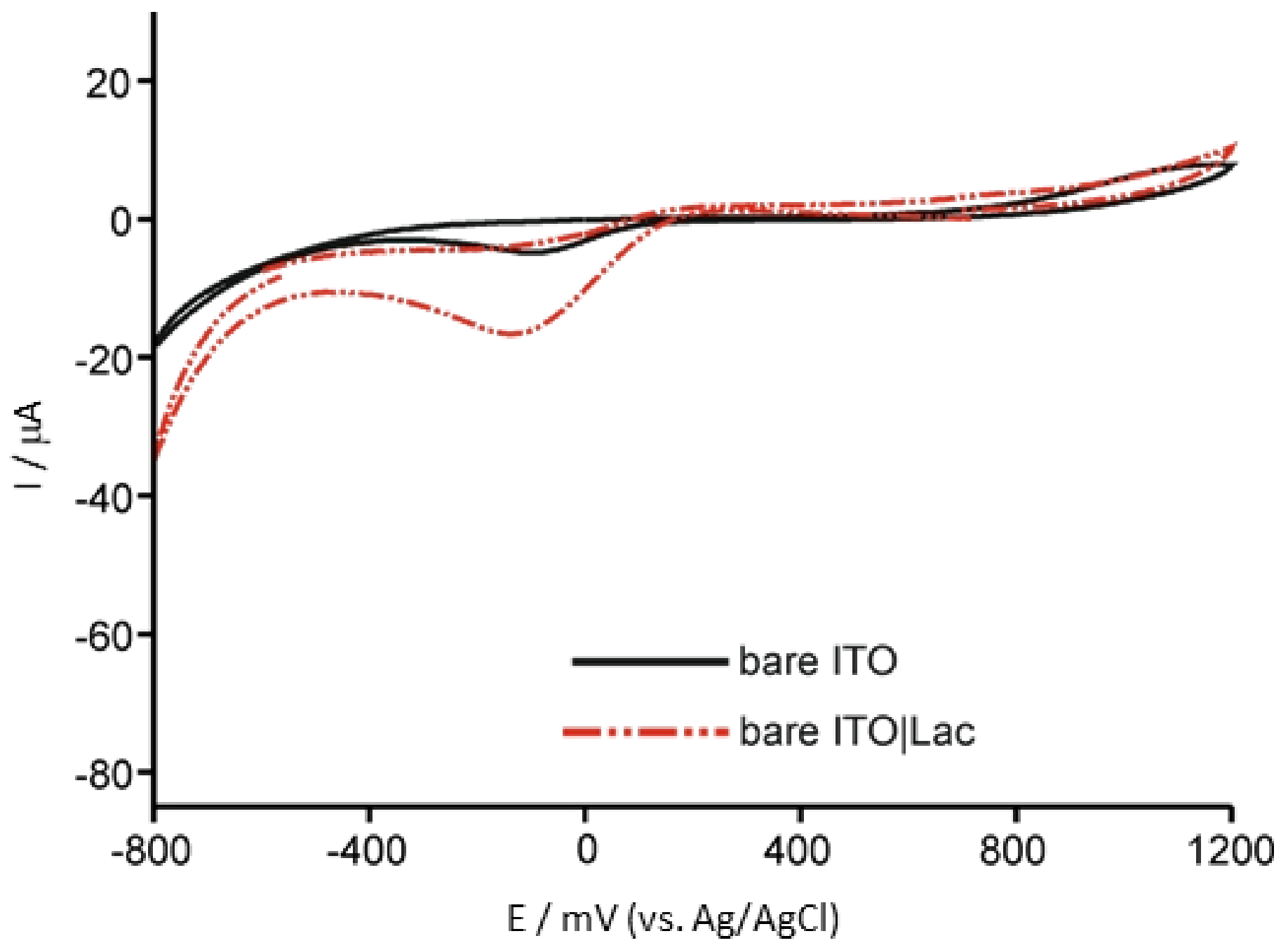




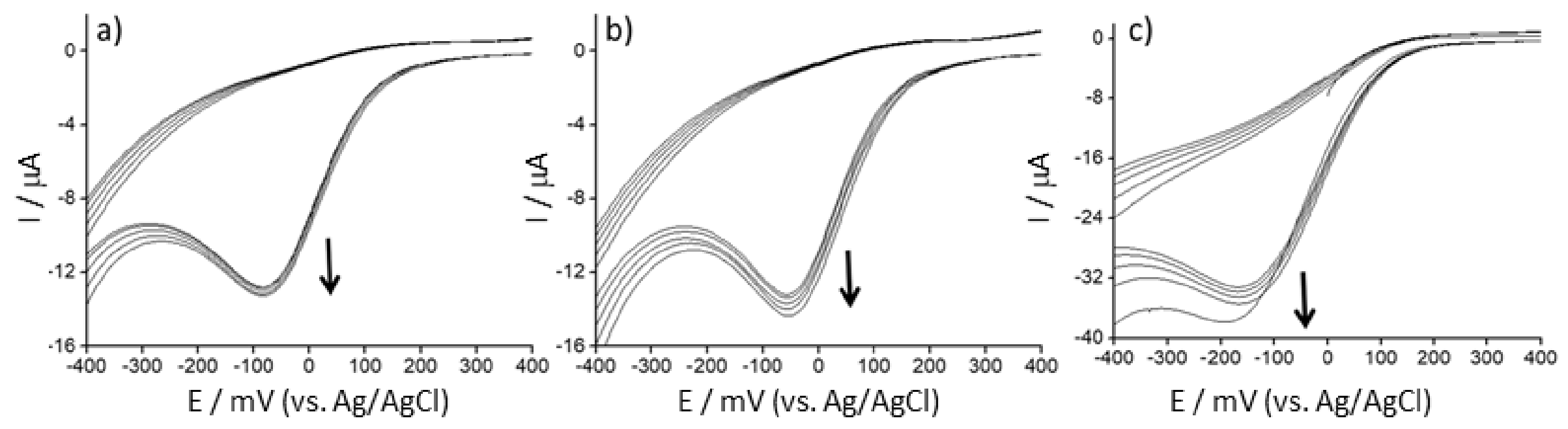



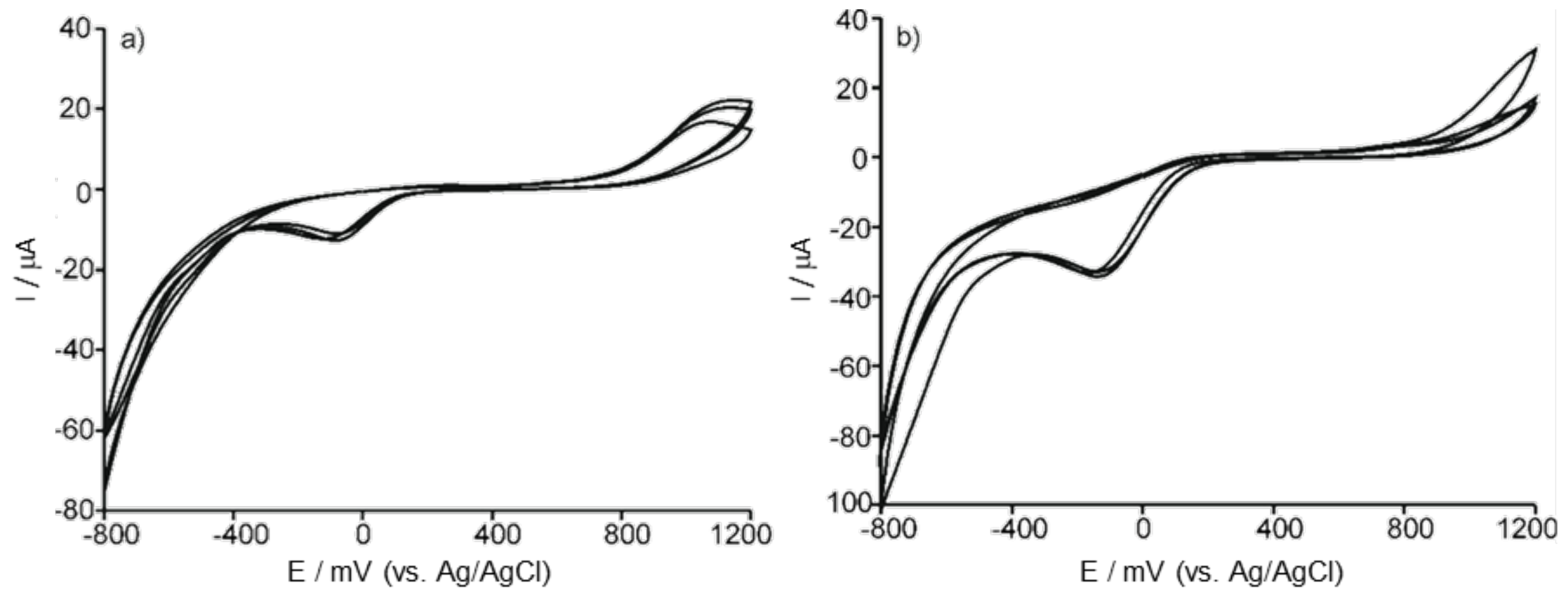
og $1:$ / V/F

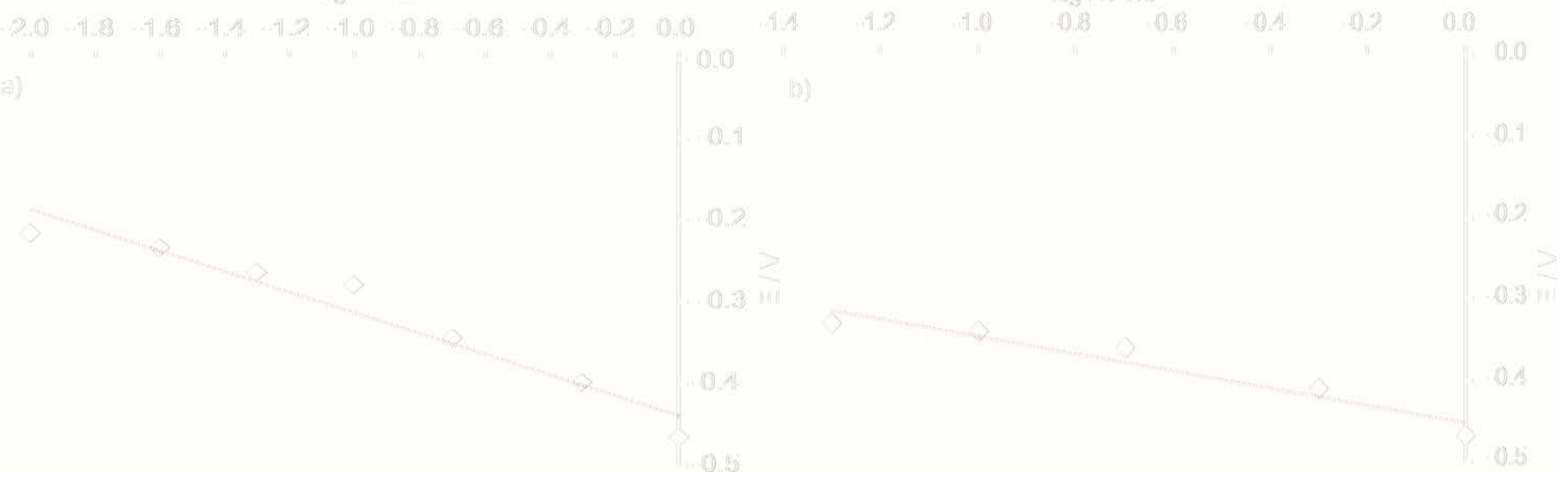



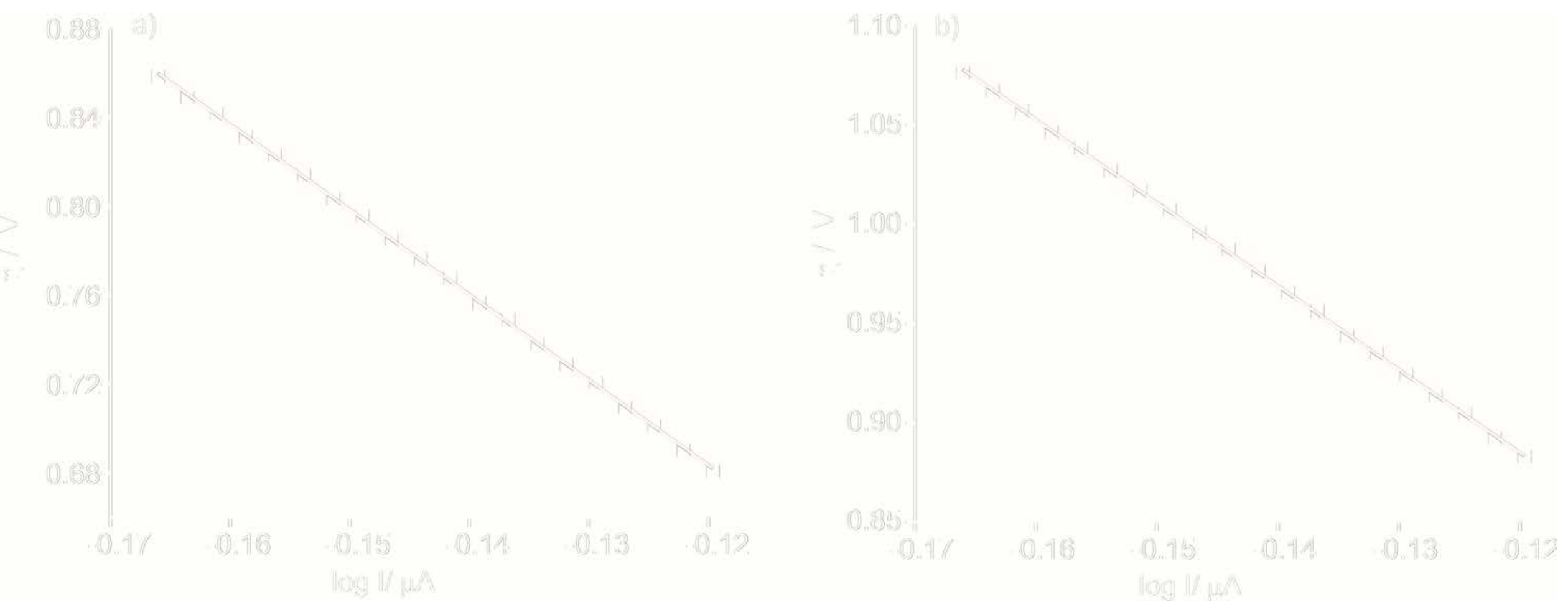